\title{
Occurrence, sources and transport pathways of natural and anthropogenic hydrocarbons in deep-sea sediments of the eastern Mediterranean Sea
}

\author{
C. Parinos ${ }^{1}$, A. Gogou ${ }^{1}$, I. Bouloubassi ${ }^{2}$, R. Pedrosa-Pàmies ${ }^{3}$, I. Hatzianestis ${ }^{1}$, A. Sanchez-Vidal ${ }^{3}$, G. Rousakis ${ }^{1}$, \\ D. Velaoras ${ }^{1}$, G. Krokos ${ }^{1}$, and V. Lykousis ${ }^{1}$ \\ ${ }^{1}$ Institute of Oceanography, Hellenic Centre for Marine Research (HCMR), 46.7 km Athens-Sounion Av., 19013 Anavyssos, \\ Attiki, Greece \\ ${ }^{2}$ Laboratoire d'Océanographie et du Climat: Expérimentation et Approches Numériques (LOCEAN), IPSL, Université Pierre \\ et Marie Curie-CNRS-IRD-MNHN, UMR 7159, 4 Place Jussieu, 75252 Paris CEDEX 05, France \\ ${ }^{3}$ GRC Geociències Marines, Departament d'Estratigrafia, Paleontologia i Geociències Marines, Facultat de Geologia, \\ Universitat de Barcelona, Barcelona, Spain
}

Correspondence to: C. Parinos (ksparinos@ hcmr.gr) and A. Gogou (agogou@hcmr.gr)

Received: 27 November 2012 - Published in Biogeosciences Discuss.: 13 December 2012

Revised: 17 July 2013 - Accepted: 22 July 2013 - Published: 24 September 2013

\begin{abstract}
Surface sediments collected from deep basins (1018-4087 m depth) of the eastern Mediterranean Sea (Ionian Sea, southern Aegean Sea and northwestern Levantine Sea) were analyzed for aliphatic and polycyclic aromatic hydrocarbons as tracers of natural and anthropogenic inputs. Concentrations of total aliphatic hydrocarbons, $n$-alkanes and the unresolved complex mixture (UCM) of aliphatic hydrocarbons varied significantly, ranging from 1.34 to $49.2 \mu \mathrm{g} \mathrm{g}^{-1}, 145$ to $4810 \mathrm{ng} \mathrm{g}^{-1}$ and 0.73 to $36.7 \mu \mathrm{g} \mathrm{g}^{-1}$, respectively, while concentrations of total polycyclic aromatic hydrocarbons (PAHs) ranged between 11.6 and $223 \mathrm{ng} \mathrm{g}^{-1}$. Molecular profiles of determined hydrocarbons reflect a mixed contribution from both natural and anthropogenic sources in deep-sea sediments of the eastern Mediterranean Sea, i.e., terrestrial plant waxes, degraded petroleum products, unburned fossil fuels and combustion of grass, wood and coal. Hydrocarbon mixtures display significant variability amongst sub-regions, reflecting differences in the relative importance of inputs from various sources and phase associations/transport pathways of individual hydrocarbons that impact on their overall distribution and fate. Hydrocarbon concentrations correlated significantly with the organic carbon content of sediments, indicating that the latter exerts an important control on their transport and ultimate accumulation in deep basins. Additionally, water masses' circulation
\end{abstract}

characteristics also seem to influence the regional features and distribution patterns of hydrocarbons. Our findings highlight the role of deep basins/canyons as repositories of both natural and anthropogenic chemical species.

\section{Introduction}

Hydrocarbons are ubiquitous components of the organic material introduced into coastal and open sites of the world's oceans. They enter the marine environment through both atmospheric (dry/wet deposition, gas exchange across the air-water interface) and aquatic pathways (direct discharges, continental run-offs, off-shelf export) the relative importance of which largely depends on the geographical setting of a given area. Although they may derive from natural sources, both marine and terrestrial, a large proportion of hydrocarbons is related to various anthropogenic activities that result in the formation and release of hazardous organic pollutants. On account of their wide variety of sources, hydrocarbons occur as complex mixtures in the marine environment (Bouloubassi et al., 1997; Gogou et al., 2000; Prahl and Carpenter, 1984; Tolosa et al., 1996; Yunker et al., 2002).

Due to their hydrophobic nature, hydrocarbons in the marine realm tend to associate with particles resulting in their 
downward transport through the water column and final accumulation in sediments (Bouloubassi et al., 2006; Dachs et al., 2002; Deyme et al., 2011; Parinos et al., 2013; Prahl and Carpenter, 1979; Tsapakis et al., 2006). The sources and physico-chemical properties of individual compounds determine their phase associations, dispersion pathways, pre- and post-deposition fate in the marine environment and their ultimate preservation in marine sediments (Dachs and Eisenreich, 2000; Simo et al., 1997; Wang et al., 1999; Yunker et al., 2002; and references therein).

Aliphatic hydrocarbons derive from natural sources such as terrestrial plant waxes, marine phytoplankton and bacteria (Brassell et al., 1978), while they are also major components of petroleum products (Wang et al., 1999). The unresolved complex mixture (UCM) of aliphatic hydrocarbons, a commonly observed contaminant mixture in marine sediments consisting of branched alicyclic hydrocarbons (Gough and Rowland, 1990), has been proven as toxic to sedimentdwelling organisms (Scarlett et al., 2007). Polycyclic aromatic hydrocarbons (PAHs) are an important and ubiquitous class of environmental contaminants. They have been classified as priority pollutants by national and international environmental agencies (e.g., EPA-US, EEA-EU) since certain homologues are highly carcinogenic and mutagenic, exhibiting tendency to bioaccumulate in aquatic organisms (Samanta et al., 2002). PAHs' formation and release in the environment is related to various anthropogenic activities including pyrolysis/combustion of organic material (biomass burning, incomplete combustion of fossil fuels) and release of petroleum products (Neff, 1979; Simoneit, 1984; Yunker et al., 2002; and references therein). PAHs of biogenic origin may also occur in environmental samples. Such evidence has been reported for perylene, retene (Laflamme and Hites, 1978; Wakeham et al., 1980) and phenanthrene (Cabrerizo et al., 2011; Nizzetto et al., 2008).

The eastern Mediterranean Sea (EMS), and especially its coastal area, is a region under intense anthropogenic pressure resulting in pollutant discharges (EEA, 2006). The open EMS, being an important region of merchant shipping and oil transportation, receives substantial amounts of petroleum discharges, mainly along shipping routes (REMPEC, 2008; UNEP, 2010). Atmospheric deposition is another important pathway for the introduction of hydrocarbons into the EMS (Castro-Jiménez et al., 2012; Gogou et al., 1996; Tsapakis et. al., 2003; Tsapakis and Stefanou, 2005) including significant inputs of Saharan dust (Jickells et al., 2005), especially during dust storm events, that contain both natural and anthropogenic hydrocarbons (Ladji et al., 2010).

Aliphatic hydrocarbons and PAHs have been investigated over the last decades in surficial sediments of the EMS, primarily in coastal or shallow basin sites in the Aegean Sea, southern Italy, the coast of Egypt and the Adriatic Sea (Aboul-Kassim and Simoneit, 1995; Alebic-Juretic, 2011; Botsou and Hatzianestis, 2012; Cardellicchio et al., 2007; Gogou et al., 2000; Gonul and Kucuksezgin, 2012; Guzzella and De Paolis, 1994; Marcomini et al., 1986; Nemr et al., 2007; Sklivagou et al., 2008; Yilmaz et al., 1998). However, there is an important lack of data regarding their occurrence in deep basins, which might represent a long-term sink for hydrocarbons. To fill this gap we report here the first data set on sedimentary aliphatic and polycyclic aromatic hydrocarbons in deep EMS basins (1018-4087 m depth). The aim of this study is to assess their occurrence, major sources and transport pathways and to evaluate the role of deep EMS basins as their repository.

\section{Oceanographic setting}

The EMS is a semi-enclosed basin that connects with the western Mediterranean Sea through the Strait of Sicily. It includes four major sub-basins: the Ionian and Levantine basins, the Adriatic Sea and the Aegean Sea.

EMS presents a complex circulation pattern, with water masses' distribution being influenced by both large-scale and mesoscale variability. As a concentration basin, it is characterized by an antiestuarine circulation that transforms surface Atlantic Waters (AW), entering through the Strait of Sicily at the upper 100-200 m of the water column, into Levantine Intermediate Waters (LIW) in the eastern part of the region (Rhodes gyre), which leave the basin as a westward current through the Strait of Sicily at depths between 200 and $500 \mathrm{~m}$. Intermediate water masses are also formed occasionally in the southern Aegean Sea (Cretan Intermediate Water-CIW), with characteristics similar to those of LIW, which feed the EMS through the Cretan Arc straits. Mesoscale variability, creating permanent and transient eddies/gyres, enhances exchanges between continental shelf waters and slope waters (Malanotte-Rizzoli et al., 1997; Millot and Taupier-Letage, 2005; Robinson et al., 1992).

Deep-water layers of the EMS originate mainly in the Adriatic Sea and are exported by means of bottom-arrested currents towards the abyssal layers of the Ionian Basin, flowing in an eastward path all the way towards the eastern Levantine Basin. The Aegean Sea also contributes to deep-water formation, and may even become more effective than the Adriatic as a deep-water source, as in the case of the Eastern Mediterranean Transient (EMT) during the early 1990s (Roether et al., 1996; Theocharis et al., 1999). The water column of the EMS is well oxygenated. The oxygen minimum found at depths of about 1000 to $2000 \mathrm{~m}$ is equivalent to $70-75 \%$ of saturation, while in deeper layers ventilation is enhanced by deep-water formation (Meador et al., 2010; Schlitzer et al., 1991).

Mean sedimentation rates in deep EMS basins are low and generally do not exceed $5 \mathrm{~cm} \mathrm{kyr}^{-1}$, mainly due to its oligotrophic character and the minor influence from riverine inputs (Garcia-Orellana et al., 2009). Thus, aeolian transport is of major importance for the delivery of land-derived natural and anthropogenic material to the open marine sites of 
the EMS. Atmospheric circulation patterns are characterized by winds of dominant north-northeast direction (central and eastern Europe and Balkans) from May to September, while from October to April the prevalence of north-northwest sector is less pronounced. Especially in March/April and in October/November winds from the north-northwest, southsouthwest (Africa) and west sectors (marine influence) are roughly equally distributed. This leads to complex aerosol dynamics, with large anthropogenic and natural emissions and intensive interaction between aerosols and gaseous pollutants, resulting in a variation of deposition modes (dry vs. wet) and composition of background aerosols in open EMS areas (Gogou et al., 1996; Lee et al., 2010; Mihalopoulos et al., 1997; Mandalakis et al., 2009; Polymenakou et al., 2008; Tsapakis and Stefanou, 2005, 2007; and references therein).

\section{Materials and methods}

\subsection{Sampling}

Sediment cores were collected with a multicorer at 22 stations in deep basins (1018-4087 m depth) of the Ionian Sea, Cretan Sea (southern Aegean Sea) and northwestern Levantine Sea during four oceanographic cruises conducted between January 2007 and June 2012 (Fig. 1, Table 1). January 2007 samples were collected during the M71 Leg. 3 cruise of the R/V Meteor (University of Hamburg, Germany), while May 2010, 2011 and June 2012 samples were collected during corresponding cruises of the R/V Aegaeo (HCMR, Greece). The undisturbed top centimeter $(1 \mathrm{~cm})$ of each core was recovered, wrapped in pre-combusted $\left(450^{\circ} \mathrm{C}, 6 \mathrm{~h}\right)$ aluminum foil and stored at $-20^{\circ} \mathrm{C}$ till further analysis.

\subsection{Methods}

For the analysis of organic carbon (OC) content, freeze-dried and grounded sediment samples were initially de-carbonated using repetitive additions of $\mathrm{HCl}(25 \%, v / v)$, separated by $60^{\circ} \mathrm{C}$ drying steps, until no effervescence was observed. Organic carbon was then determined by combustion in an oxygen atmosphere and the produced carbon dioxide was quantitatively measured using a Flash 1112 elemental analyzer.

For the analysis of aliphatic and polycyclic aromatic hydrocarbons freeze-dried sediments were spiked with a mixture of perdeuterated internal standards $\quad\left(\left[{ }^{2} \mathrm{H}_{50}\right] n\right.$-tetracosane, $\quad\left[{ }^{2} \mathrm{H}_{10}\right]$ phenanthrene, $\left[{ }^{2} \mathrm{H}_{10}\right]$ pyrene, $\left[{ }^{2} \mathrm{H}_{12}\right]$ chrysene, $\left[{ }^{2} \mathrm{H}_{12}\right]$ perylene and $\left[{ }^{2} \mathrm{H}_{12}\right]$ benzo[ghi]perylene) and solvent extracted three times by sonication with a dichloromethane:methanol mixture $(4: 1, v / v)$. Combined extracts were fractionated on a silica column, applying a modified protocol after Gogou et al. (1998). Aliphatic hydrocarbons were eluted with $6 \mathrm{~mL}$ $n$-hexane and PAHs with $10 \mathrm{~mL} n$-hexane/toluene $(9: 1$, $v / v$ ). Both fractions were concentrated by vacuum rotary
Table 1. Location and characteristics of sampling sites.

\begin{tabular}{|c|c|c|c|c|c|}
\hline \multirow[t]{2}{*}{ Station } & \multicolumn{2}{|c|}{ Location } & \multirow{2}{*}{$\begin{array}{c}\text { Water } \\
\text { depth }(m)\end{array}$} & \multirow{2}{*}{$\begin{array}{c}\text { Sampling } \\
\text { date }\end{array}$} & \multirow{2}{*}{$\begin{array}{c}\text { Organic } \\
\text { carbon }(\%)\end{array}$} \\
\hline & Lat. N & Long. E & & & \\
\hline RED2.1 & $33^{\circ} 42.81^{\prime}$ & $26^{\circ} 20.45^{\prime}$ & 2720 & May 2010 & 0.37 \\
\hline RED3 & $35^{\circ} 24.14^{\prime}$ & $23^{\circ} 24.10^{\prime}$ & 2976 & May 2010 & 0.37 \\
\hline RED3.1 & $35^{\circ} 18.17^{\prime}$ & $23^{\circ} 18.92^{\prime}$ & 3314 & May 2010 & 0.58 \\
\hline RED4 & $35^{\circ} 45.71^{\prime}$ & $25^{\circ} 06.00^{\prime}$ & 1620 & May 2010 & 0.42 \\
\hline RED5 & $35^{\circ} 40.57^{\prime}$ & $25^{\circ} 06.12^{\prime}$ & 1018 & May 2010 & 0.39 \\
\hline RED7 & $34^{\circ} 36.11^{\prime}$ & $24^{\circ} 08.73^{\prime}$ & 3589 & May 2011 & 0.51 \\
\hline RED8 & $36^{\circ} 04.47^{\prime}$ & $25^{\circ} 17.07^{\prime}$ & 1715 & May 2011 & 0.33 \\
\hline RED9 & $36^{\circ} 00.03^{\prime}$ & $23^{\circ} 53.55^{\prime}$ & 1200 & May 2011 & 0.40 \\
\hline RED1.1 & $34^{\circ} 24.13^{\prime}$ & $26^{\circ} 14.67^{\prime}$ & 3568 & Jun 2012 & 0.54 \\
\hline RED15.1 & $34^{\circ} 36.55^{\prime}$ & $25^{\circ} 55.49^{\prime}$ & 2428 & Jun 2012 & 0.62 \\
\hline RED13 & $34^{\circ} 57.01^{\prime}$ & $25^{\circ} 54.90^{\prime}$ & 1101 & Jun 2012 & 0.46 \\
\hline H01 & $35^{\circ} 45.00^{\prime}$ & $23^{\circ} 00.00^{\prime}$ & 2117 & Jan 2007 & 0.29 \\
\hline H02 & $35^{\circ} 45.00^{\prime}$ & $21^{\circ} 00.00^{\prime}$ & 3008 & Jan 2007 & 0.45 \\
\hline H03 & $35^{\circ} 45.00^{\prime}$ & $18^{\circ} 30.00^{\prime}$ & 4087 & Jan 2007 & 0.63 \\
\hline H04 & $35^{\circ} 55.00^{\prime}$ & $16^{\circ} 00.00^{\prime}$ & 3750 & Jan 2007 & 0.65 \\
\hline H05 & $37^{\circ} 30.00^{\prime}$ & $18^{\circ} 30.00^{\prime}$ & 3154 & Jan 2007 & 0.57 \\
\hline H07 & $39^{\circ} 10.00^{\prime}$ & $17^{\circ} 45.00^{\prime}$ & 1866 & Jan 2007 & 1.15 \\
\hline H12 & $38^{\circ} 50.00^{\prime}$ & $19^{\circ} 45.00^{\prime}$ & 1450 & Jan 2007 & 0.15 \\
\hline Her01 & $33^{\circ} 55.44^{\prime}$ & $27^{\circ} 44.45^{\prime}$ & 2680 & Jan 2007 & 0.31 \\
\hline Her03 & $33^{\circ} 40.00^{\prime}$ & $29^{\circ} 00.00^{\prime}$ & 3090 & Jan 2007 & 0.49 \\
\hline IER01 & $34^{\circ} 26.54^{\prime}$ & $26^{\circ} 11.51^{\prime}$ & 3626 & Jan 2007 & 0.52 \\
\hline Rho02 & $35^{\circ} 37.12^{\prime}$ & $27^{\circ} 42.03^{\prime}$ & 1305 & Jan 2007 & 0.47 \\
\hline
\end{tabular}

evaporation, transferred to a $1.5 \mathrm{~mL}$ amber vial and excess solvent was evaporated under a gentle nitrogen stream.

Instrumental analysis was carried out by gas chromatography mass spectrometry (GC-MS) on an Agilent 7890 GC, equipped with an HP-5MS capillary column $(30 \mathrm{~m} \times 0.25 \mathrm{~mm}$ i.d. $\times 0.25 \mu \mathrm{m}$ phase film), coupled to an Agilent 5975C MSD. For the analysis of aliphatic hydrocarbons the MSD operated in full scan mode and the GC oven temperature was initially held at $60^{\circ} \mathrm{C}$ for $2 \mathrm{~min}$, brought to $80^{\circ} \mathrm{C}$ at a rate of $25^{\circ} \mathrm{C} \mathrm{min}^{-1}$, then to $300^{\circ} \mathrm{C}$ at a rate of $5^{\circ} \mathrm{C} \mathrm{min}^{-1}$ and finally held at $300^{\circ} \mathrm{C}$ for $35 \mathrm{~min}$. PAHs were analyzed using a selected ion monitoring (SIM) acquisition program. The oven temperature program was the same as in the case of aliphatic hydrocarbons but with a $300{ }^{\circ} \mathrm{C}$ final isothermal of $6 \mathrm{~min}$. Helium was used as carrier gas at a flow of $1.1 \mathrm{~mL} \mathrm{~min}^{-1}$.

Standard solutions of the targeted compounds, purchased from Dr. Ehrenstorfer GmbH, were spiked with the internal standards and run on each injection set in order to derive relative response factors (RRFs) of the analytes. The precision of the analytical method used for PAHs determination was evaluated by analyzing the standard reference material SRM $1941 \mathrm{~b}$ - NIST USA (organics in marine sediment). The determined values ranged between 93 and $106 \%$ of the certified values, while in terms of repeatability the relative standard deviation was below $5 \%$. Procedural blanks processed were found to be free of contamination.

Cluster analysis (joining clustering method) was applied to group stations with similar $n$-alkane or PAH profiles, using the relative homologues' concentrations for the total sum of compounds monitored, respectively, as starting data. 


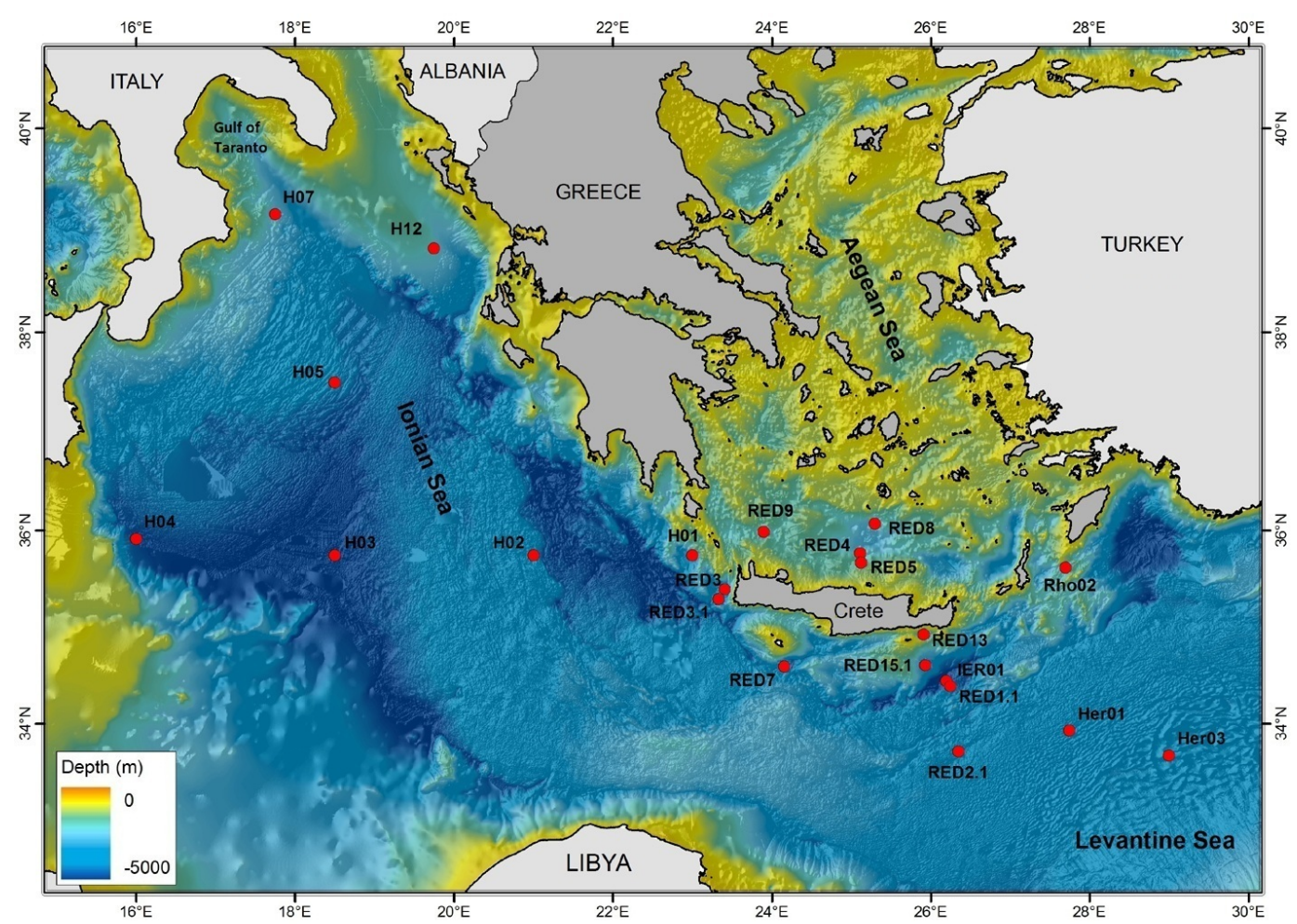

Fig. 1. Location of sampling sites across the eastern Mediterranean Sea (see also Table 1). The map was produced using the GEBCO Digital Atlas (IOC, IHO and BODC, 2003).

Ward's method was used for amalgamation of clusters while distances between objects were measured as Euclidean distances.

Spatial distributions of concentrations and characteristic parameters of aliphatic and polycyclic aromatic hydrocarbons were visualized using Ocean Data View - ODV (Schlitzer, 2011).

\section{Results}

\subsection{Organic carbon}

Organic carbon (OC) contents ranged from 0.15 to $1.15 \%$ (Table 1). These values are comparable to those reported for the open northwestern Mediterranean Sea $(0.38-1.47 \%$, Bouloubassi et al., 1997; 0.23-1.85\%, Roussiez et al., 2006; 0.7-1.5\%, Tolosa et al., 1996) and the open Cretan Sea (0.30-0.82\%; Gogou et al., 2000). Maximum values are found off the Gulf of Taranto (station H07), followed by deep Ionian Sea basins (stations H04 and H03), while minimum values are found in the northeastern Ionian Sea (station H12).

\subsection{Molecular profile of hydrocarbons}

Sedimentary aliphatic hydrocarbons comprised of a series of resolved compounds, mainly $n$-alkanes (NA), and a UCM.
$\mathrm{C}_{12}$ to $\mathrm{C}_{42} n$-alkanes were the main resolved constituents, representing on average $56 \%$ of their total sum. Their molecular profile (Fig. 2a) was dominated by long-chain homologues $\left(\mathrm{C}_{n} \geq 24\right)$ maximizing at $n$ - $\mathrm{C}_{31}$ with an elevated odd/even carbon preference index $\left(\mathrm{CPI}_{24-35}=4.86\right.$ on average, Table 2). NA with $\mathrm{C}_{n}>35$ constituted a large fraction at some stations ( $>30 \%$ ), while $\mathrm{C}_{n} \leq 23$ NA without odd/even carbon preference $\left(\mathrm{CPI}_{14-23} \sim 1\right)$ were also abundant in others $(\sim 15 \%$ on average). A UCM, present as a unimodal hump centered around $n-\mathrm{C}_{30}$, was the major component of aliphatic hydrocarbons accounting for up to $81 \%$ of their total sum (69\% on average).

Twenty-five PAHs comprising parent (unsubstituted) compounds with 3-6 rings and alkyl-substituted homologues were determined. A typical PAH molecular profile is presented in Fig. 2b. Phenanthrene and its alkylated homologues dominated amongst low-MW PAHs (3 rings). Their sum, referred to hereafter as $\sum$ Phe, accounted for $23 \pm 6 \%$ of total PAHs. High-MW parent compounds ( $\geq 4$ rings) were dominated by benzofluoranthenes, indeno[1,2,3-cd]pyrene and, to a lesser degree, chrysene. Their sum, referred to hereafter as $\sum \mathrm{COMB}$, excluding perylene which may have natural sources (Venkatesan, 1988), represents $55 \pm 8 \%$ of total PAHs. 

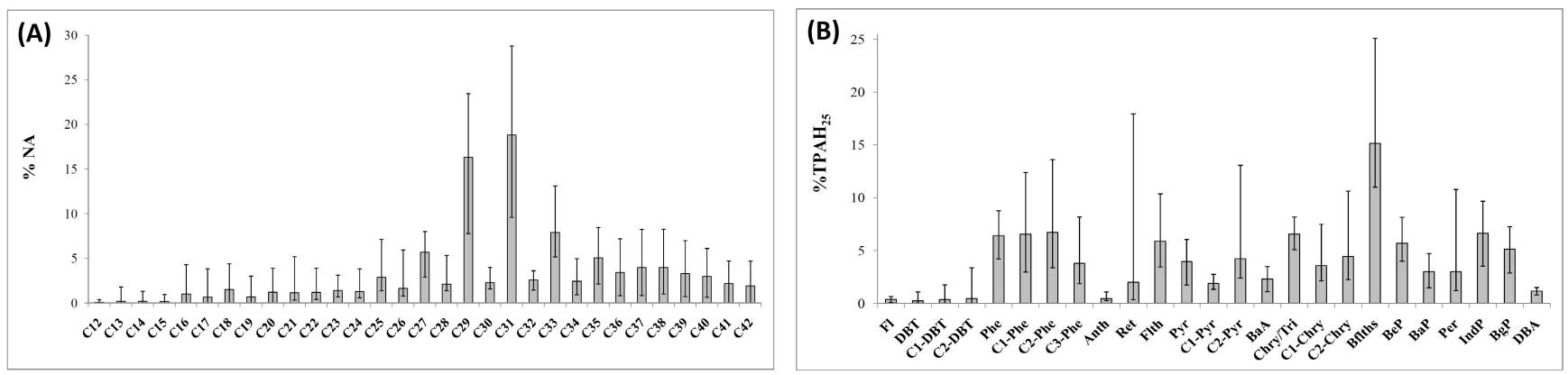

Fig. 2. Molecular profile of $n$-alkanes (A) and PAHs (B) in deep-sea sediments of the study area. Individual compound abundances are normalized as percentage of the total sum of NA or PAHs (TPAH 25$)$, respectively, and presented along with min-max deviation lines. NA homologues are assigned with their number of carbon atoms. PAH abbreviations: fluorene (Fl), dibenzothiophene (DBT), methyldibenzothiophenes $\left(\mathrm{C}_{1}\right.$-DBT), dimethyldibenzothiophenes $\left(\mathrm{C}_{2}\right.$-DBT), phenanthrene (Phe), methylphenanthrenes $\left(\mathrm{C}_{1}\right.$-Phe), dimethylphenanthrenes $\left(\mathrm{C}_{2}\right.$-Phe), trimethylphenanthrenes $\left(\mathrm{C}_{3}\right.$-Phe), anthracene (Anth), fluoranthene (Flth), pyrene (Pyr), methylpyrenes $\left(\mathrm{C}_{1}-\mathrm{Pyr}\right)$, dimethylpyrenes $\left(\mathrm{C}_{2}\right.$-Pyr), retene (Ret), benz $[a]$ anthracene $(\mathrm{BaA})$, chrysene/triphenylene (Chry/Tri), methylchrysenes $\left(\mathrm{C}_{1}\right.$-Chry), dimethylchrysenes $\left(\mathrm{C}_{2}-\right.$ Chry), benzo[b/j/k]fluoranthenes (BFlths), benzo[e]pyrene (BeP), benzo[ $[a]$ pyrene (BaP), perylene (Per), indeno[1,2,3-cd]pyrene (IndP), benzo[ghi]perylene $(\mathrm{BgP})$ and $\operatorname{dibenz}[a, h]$ anthracene $(\mathrm{DBA})$.

Table 2. Concentrations (per dry weight and OC-normalized) and characteristic parameters of aliphatic hydrocarbons determined in deep-sea sediments of the eastern Mediterranean Sea.

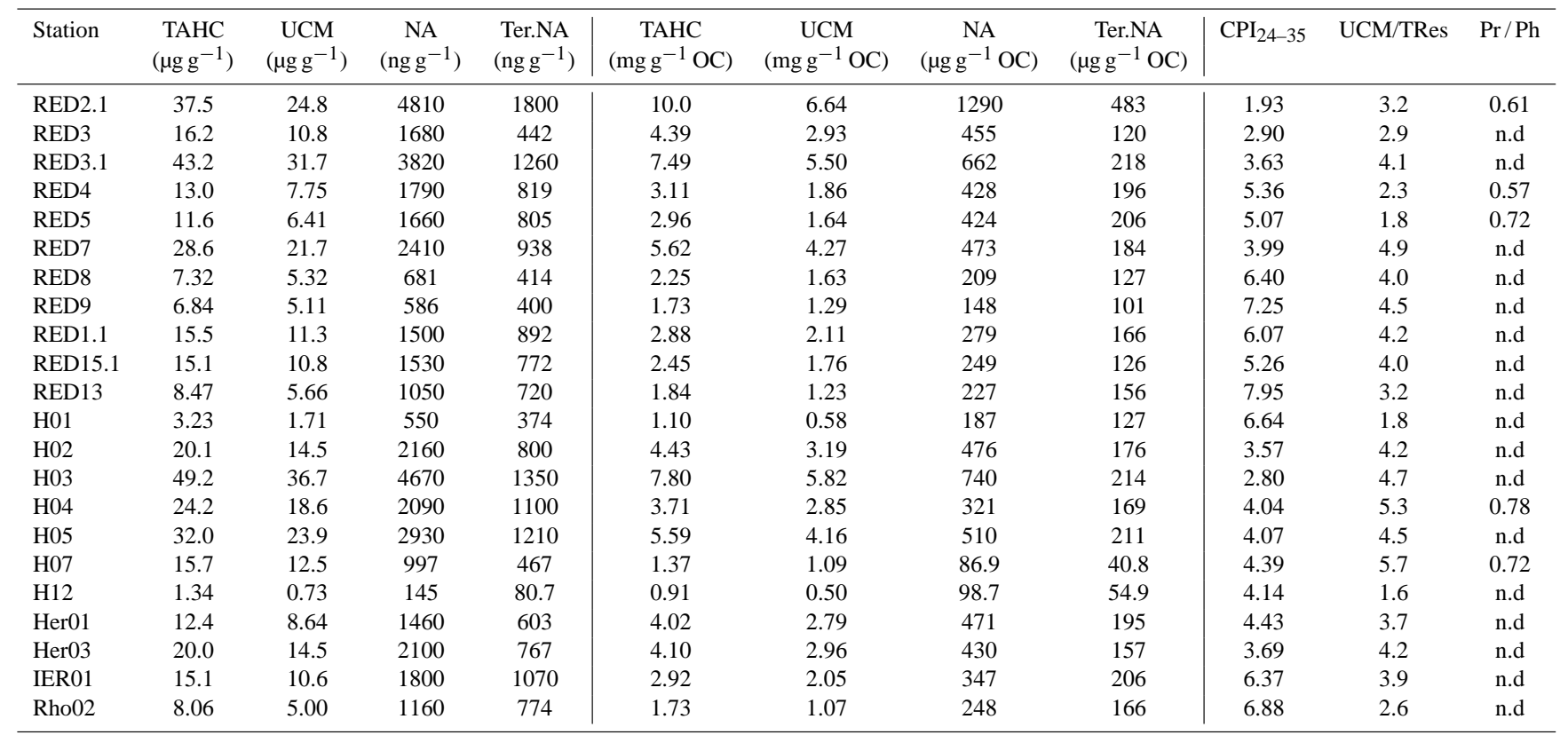

TAHC: total aliphatic hydrocarbons (sum of total resolved compounds and UCM); UCM: unresolved complex mixture; NA: $n$-alkanes; Ter.NA: sum of terrestrial $n$-alkanes $\left(n-\mathrm{C}_{27}, n-\mathrm{C}_{29}, n-\mathrm{C}_{31}\right.$ and $\left.n-\mathrm{C}_{33}\right) ; \mathrm{CPI}_{24-35}$ : carbon preference index in the carbon range $n-\mathrm{C}_{24}$ to $n-\mathrm{C}_{35}$; UCM/TRes: relative abundance of UCM compared to total resolved aliphatic hydrocarbons (TRes); Pr: pristane; Ph: phytane; n.d: not detected.

\subsection{Concentrations and spatial distribution of hydrocarbons}

Concentrations of total aliphatic hydrocarbons (TAHC: sum of resolved compounds and UCM), UCM and NA in the study area are presented in Table 2. TAHC and UCM concentrations varied significantly, ranging from 1.34 to $49.2 \mu \mathrm{g} \mathrm{g}^{-1}$ (average $18.4 \mu \mathrm{g} \mathrm{g}^{-1}$ ) and 0.73 to $36.7 \mu \mathrm{g} \mathrm{g}^{-1}$ (average $13.1 \mu \mathrm{g} \mathrm{g}^{-1}$ ), respectively, while NA concentrations ranged between 145 and $4810 \mathrm{ng} \mathrm{g}^{-1}$, averaging $1890 \mathrm{ng} \mathrm{g}^{-1}$. Normalized to OC content, TAHC, UCM and NA concentrations ranged from 0.91 to $10.0 \mathrm{mg} \mathrm{g}^{-1} \mathrm{OC}$ (average $3.75 \mathrm{mg} \mathrm{g}^{-1} \mathrm{OC}$ ), 0.50 to $6.64 \mathrm{mg} \mathrm{g}^{-1} \mathrm{OC}$ (aver-

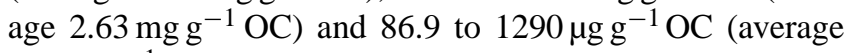
$398 \mu \mathrm{g} \mathrm{g}^{-1}$ OC), respectively. 
A TAHC $\left[\mu^{-1} g^{-1}\right]$

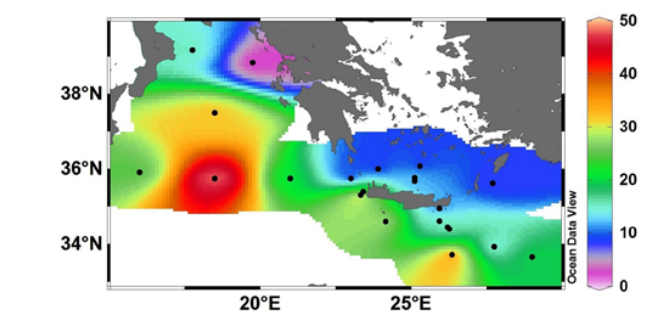

B

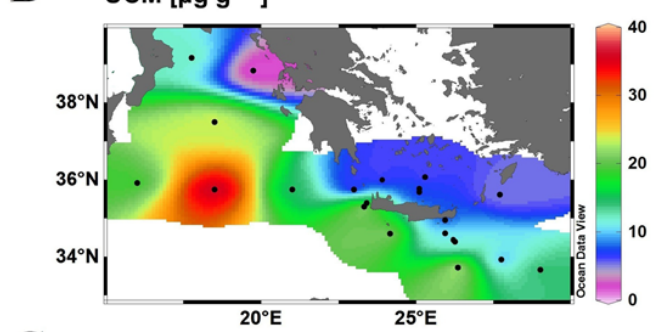

C

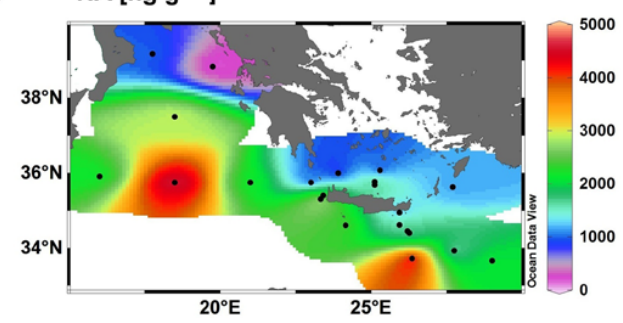

D

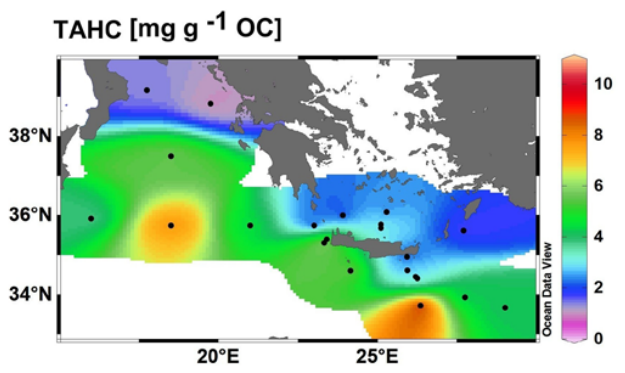

E

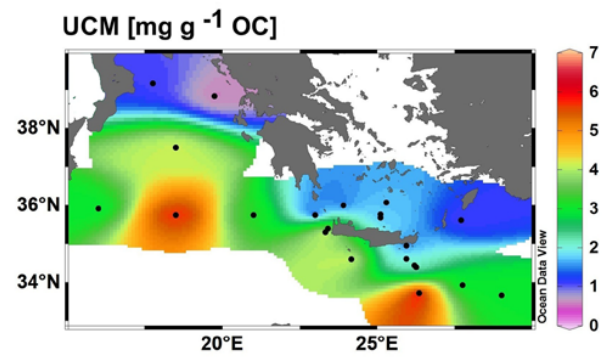

F

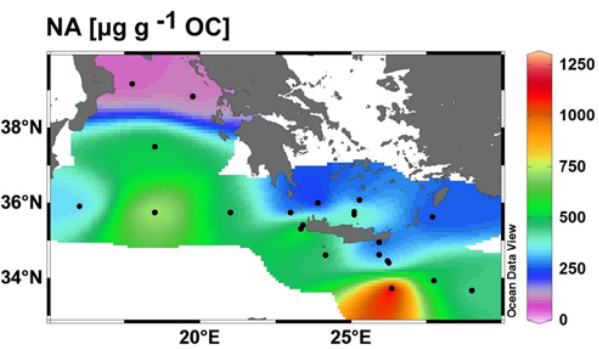

Fig. 3. Spatial contour maps of TAHC, UCM and NA absolute (per dry weight) and their OC-normalized concentrations in deep-sea sediments across the eastern Mediterranean Sea. TAHC, UCM and NA are defined in the text.

Spatial distributions of absolute (per dry weight) and OC-normalized TAHC, UCM and NA concentrations in the study area are illustrated in Fig. 3. The highest TAHC levels were recorded in central Ionian Sea deep basins (average $31.4 \mu \mathrm{g} \mathrm{g}^{-1}$ or $5.38 \mathrm{mg} \mathrm{g}^{-1} \mathrm{OC}$ ), followed by deep northwestern Levantine basins (average $19.3 \mu \mathrm{g} \mathrm{g}^{-1}$ or $4.40 \mathrm{mg} \mathrm{g}^{-1} \mathrm{OC}$ ), while lower values were recorded at Cre$\tan$ Sea stations (average $9.69 \mu \mathrm{g} \mathrm{g}^{-1}$ or $2.51 \mathrm{mg} \mathrm{g}^{-1} \mathrm{OC}$ ). In deep basins of the Ionian Sea and the northwestern Levantine Sea, TAHC, UCM and NA absolute and OC-normalized concentrations display generally a common increasing westward trend, with maximum concentrations recorded at station $\mathrm{H} 03$ in the central Ionian Sea and station RED2.1 located in the northwestern Levantine Sea. An almost twofold increase is observed in the concentrations of aliphatic hydrocarbons at the deep station of the western Cretan Straits' canyons (RED3.1) in comparison to the neighboring RED3 located in the upper slope of the adjacent margin. Minimum TAHC, UCM and NA absolute and OC-normalized concentrations were recorded at station $\mathrm{H} 12$ in the northeastern Ionian Sea (Table 2).

Table 3 summarizes concentrations of PAHs in the study area. $\mathrm{TPAH}_{25}$ refers to the total sum of compounds monitored, while $\sum \mathrm{PAH}_{13}$ refers to the sum of 13 parent compounds mostly considered in environmental studies, i.e., Fl, Phe, Anth, Flth, Pyr, BaA, Chry, BFlths, BeP, $\mathrm{BaP}$, IndP, BgP and DBA (for abbreviations, see Fig. 2). $\mathrm{TPAH}_{25}$ and $\sum \mathrm{PAH}_{13}$ concentrations ranged from 11.6 to $223 \mathrm{ng} \mathrm{g}^{-1}$ (average $63.6 \mathrm{ng} \mathrm{g}^{-1}$ ) and from 5.90 to $130 \mathrm{ng} \mathrm{g}^{-1}$ (average $38.3 \mathrm{ng} \mathrm{g}^{-1}$ ), respectively. The concentrations of $\sum$ COMB ranged from 5.08 to $118 \mathrm{ng} \mathrm{g}^{-1}$ (average $33.9 \mathrm{ng} \mathrm{g}^{-1}$ ), while $\sum$ Phe ranged between 2.74 and $38.3 \mathrm{ng} \mathrm{g}^{-1}$, averaging $15.0 \mathrm{ng} \mathrm{g}^{-1}$. Normalized to OC content, $\mathrm{TPAH}_{25}, \sum \mathrm{COMB}$ and $\sum \mathrm{Phe}$ concentrations ranged from 3.92 to $38.8 \mu \mathrm{g} \mathrm{g}^{-1} \mathrm{OC}$ (average $12.8 \mu \mathrm{g} \mathrm{g}^{-1} \mathrm{OC}$ ), 1.73 to $20.6 \mu \mathrm{g} \mathrm{g}^{-1} \mathrm{OC}$ (average $6.90 \mu \mathrm{g} \mathrm{g}^{-1} \mathrm{OC}$ ) and 0.80 to $7.28 \mu \mathrm{g} \mathrm{g}^{-1}$ OC (average $3.01 \mu \mathrm{g} \mathrm{g}^{-1} \mathrm{OC}$ ), respectively.

Spatial distributions of absolute (per dry weight) and OCnormalized $\mathrm{TPAH}_{25}, \sum \mathrm{Phe}$ and $\sum \mathrm{COMB}$ concentrations in the study area are illustrated in Fig. 4. The highest $\mathrm{TPAH}_{25}$ levels were recorded at central Ionian Sea deep stations (average $118 \mathrm{ng} \mathrm{g}^{-1}$ or $20.0 \mu \mathrm{g} \mathrm{g}^{-1} \mathrm{OC}$ ), while lower concentrations were recorded at both northwestern Levantine deep basins (average $49.5 \mathrm{ng} \mathrm{g}^{-1}$ or $10.1 \mu \mathrm{gg}^{-1} \mathrm{OC}$ ) and Cre$\tan$ Sea stations (average $41.9 \mathrm{ng} \mathrm{g}^{-1}$ or $9.28 \mu \mathrm{g} \mathrm{g}^{-1} \mathrm{OC}$ ). $\mathrm{TPAH}_{25}$ absolute and OC-normalized concentrations display, as in the case of sedimentary aliphatic hydrocarbons, a common increasing westward trend, with maximum 
Table 3. Concentrations (per dry weight and OC-normalized), characteristic parameters and source-specific diagnostic ratios of polycyclic aromatic hydrocarbons (PAHs) determined in deep-sea sediments of the eastern Mediterranean Sea.

\begin{tabular}{|c|c|c|c|c|c|c|c|c|c|c|c|c|}
\hline Station & $\begin{array}{l}\mathrm{TPAH}_{25} \\
\left(\mathrm{ng} \mathrm{g}^{-1}\right)\end{array}$ & $\begin{array}{c}\sum_{\left(\mathrm{ng} \mathrm{g}^{-1}\right)} \\
\mathrm{PAH}_{13}\end{array}$ & $\underset{\left(n g^{-1}\right)}{\sum \mathrm{COMB}}$ & $\begin{array}{c}\sum \mathrm{Phe} \\
\left(\mathrm{ng} \mathrm{g}^{-1}\right)\end{array}$ & $\begin{array}{c}\mathrm{TPAH}_{25} \\
\left(\mu \mathrm{gg}^{-1} \mathrm{OC}\right)\end{array}$ & $\begin{array}{c}\sum \mathrm{COMB} \\
\left(\mu \mathrm{gg} \mathrm{g}^{-1} \mathrm{OC}\right)\end{array}$ & $\begin{array}{c}\sum \mathrm{Phe} \\
\left(\mu \mathrm{g} \mathrm{g}^{-1} \mathrm{OC}\right)\end{array}$ & $\begin{array}{c}\sum \text { Phe } / \\
\sum \text { COMB }\end{array}$ & $\begin{array}{c}\mathrm{C}_{0} /\left(\mathrm{C}_{0}+\mathrm{C}_{1}\right) \\
\text { Phe }\end{array}$ & $\begin{array}{c}\text { Flth / } \\
(\text { Flth + Pyr) }\end{array}$ & $\begin{array}{c}\mathrm{BaA} / \\
(\mathrm{BaA}+\mathrm{Chry})\end{array}$ & $\begin{array}{c}\text { IndP/ } \\
(\text { IndP }+ \text { BgP) }\end{array}$ \\
\hline RED2.1 & 59.7 & 36.4 & 31.0 & 17.4 & 16.0 & 8.31 & 4.67 & 0.56 & 0.43 & 0.53 & 0.27 & 0.58 \\
\hline RED3 & 51.4 & 32.0 & 28.0 & 13.2 & 13.9 & 7.58 & 3.58 & 0.47 & 0.42 & 0.56 & 0.22 & 0.59 \\
\hline RED3.1 & 109 & 63.2 & 54.2 & 33.3 & 18.9 & 9.40 & 5.78 & 0.61 & 0.39 & 0.58 & 0.26 & 0.58 \\
\hline RED4 & 52.0 & 28.9 & 24.4 & 18.3 & 12.4 & 5.84 & 4.37 & 0.75 & 0.38 & 0.52 & 0.28 & 0.61 \\
\hline RED5 & 50.0 & 34.5 & 30.5 & 11.4 & 12.8 & 7.79 & 2.91 & 0.37 & 0.46 & 0.55 & 0.29 & 0.59 \\
\hline RED7 & 114 & 50.8 & 42.6 & 37.1 & 22.4 & 8.36 & 7.28 & 0.87 & 0.39 & 0.63 & 0.24 & 0.55 \\
\hline RED8 & 40.2 & 27.2 & 24.3 & 8.01 & 12.3 & 7.45 & 2.46 & 0.33 & 0.56 & 0.59 & 0.28 & 0.57 \\
\hline RED9 & 25.5 & 18.6 & 17.2 & 4.34 & 6.45 & 4.35 & 1.10 & 0.25 & 0.50 & 0.60 & 0.25 & 0.57 \\
\hline RED1.1 & 39.6 & 27.8 & 24.5 & 7.43 & 7.37 & 4.55 & 1.38 & 0.30 & 0.62 & 0.60 & 0.28 & 0.56 \\
\hline RED15.1 & 32.0 & 24.1 & 22.3 & 4.91 & 5.21 & 3.63 & 0.80 & 0.22 & 0.57 & 0.60 & 0.26 & 0.59 \\
\hline RED13 & 39.1 & 25.4 & 22.0 & 9.12 & 8.49 & 4.78 & 1.98 & 0.41 & 0.52 & 0.58 & 0.25 & 0.51 \\
\hline H01 & 11.6 & 5.90 & 5.08 & 4.42 & 3.92 & 1.73 & 1.50 & 0.87 & 0.33 & 0.59 & 0.21 & 0.55 \\
\hline H02 & 41.2 & 30.7 & 27.6 & 7.46 & 9.07 & 6.07 & 1.64 & 0.27 & 0.63 & 0.58 & 0.26 & 0.58 \\
\hline H03 & 93.9 & 54.4 & 49.5 & 19.2 & 14.9 & 7.85 & 3.04 & 0.39 & 0.50 & 0.61 & 0.22 & 0.54 \\
\hline H04 & 113 & 60.4 & 55.1 & 24.3 & 17.4 & 8.46 & 3.73 & 0.44 & 0.46 & 0.58 & 0.27 & 0.51 \\
\hline H05 & 223 & 130 & 118 & 38.3 & 38.8 & 20.6 & 6.67 & 0.32 & 0.55 & 0.65 & 0.35 & 0.54 \\
\hline H07 & 118 & 70.4 & 61.2 & 31.7 & 10.3 & 5.34 & 2.77 & 0.52 & 0.51 & 0.59 & 0.28 & 0.54 \\
\hline $\mathrm{H} 12$ & 17.5 & 9.58 & 8.26 & 2.74 & 11.9 & 5.63 & 1.86 & 0.33 & 0.70 & 0.67 & 0.15 & 0.58 \\
\hline Her01 & 45.3 & 32.7 & 28.7 & 8.53 & 14.6 & 9.27 & 2.76 & 0.30 & 0.65 & 0.62 & 0.32 & 0.55 \\
\hline Her03 & 29.9 & 20.9 & 18.9 & 6.04 & 6.13 & 3.88 & 1.24 & 0.32 & 0.57 & 0.66 & 0.25 & 0.57 \\
\hline IER01 & 42.7 & 23.4 & 21.0 & 12.7 & 8.24 & 4.06 & 2.44 & 0.60 & 0.44 & 0.63 & 0.19 & 0.58 \\
\hline Rho02 & 50.0 & 36.2 & 31.5 & 10.0 & 10.7 & 6.75 & 2.14 & 0.32 & 0.63 & 0.64 & 0.24 & 0.54 \\
\hline
\end{tabular}

$\mathrm{TPAH}_{25}$ : total sum of polycyclic aromatic hydrocarbons; $\sum \mathrm{PAH}_{13}$ : sum of 13 parent compounds mainly considered in marine pollution studies (i.e., Fl, Phe, Anth, Flth, Pyr, BaA, Chry, BFlths, BeP, BaP, IndP, BgP and DBA); $\sum$ COMB: sum of high MW parent compounds ( $\geq 4$ rings) excluding perylene; $\sum$ Phe: sum of Phe, $\mathrm{C}_{1}$-Phe, $\mathrm{C}_{2}$-Phe and $\mathrm{C}_{3}$-Phe; abbreviations of PAH compounds are presented in Fig. 2.

concentrations found in the central Ionian Sea (station $\mathrm{H} 05,223 \mathrm{ng} \mathrm{g}^{-1}$ or $38.8 \mu \mathrm{gg}^{-1} \mathrm{OC}$ ), associated with maxima for both $\sum$ Phe and $\sum$ COMB concentrations. Secondary $\mathrm{TPAH}_{25}$ maxima were recorded at stations H07 (northwestern Ionian Sea) and RED7 (southern Crete), while a significant increase is observed for $\mathrm{TPAH}_{25}$ absolute and OCnormalized concentrations at the deep station of the western Cretan Straits' canyons (RED3.1) in comparison to the neighboring RED3 located in the upper slope of the adjacent margin. Minimum PAH concentrations were recorded at station $\mathrm{H} 12$ in the northeastern Ionian Sea and station H01 in the western Cretan Straits (Table 3).

\section{Discussion}

\subsection{Aliphatic and polycyclic aromatic hydrocarbons levels}

Concentrations of total aliphatic hydrocarbons in the investigated deep basins of the EMS are comparable to those reported for surface sediments in unpolluted to moderately polluted coastal and/or open-sea areas in the Mediterranean, such as the Cretan Sea (Gogou et al., 2000), the north Aegean Sea (Hatzianestis et al., 1998), the open northwestern Mediterranean Sea (Tolosa et al., 1996), and in other sites worldwide, e.g., the East China Sea (Bouloubassi et al., 2001), the open Black Sea (Wakeham, 1996) and southern New England (Venkatesan et al., 1987). They are at least one order of magnitude lower than those reported for coastal areas subjected to enhanced urban and/or fluvial inputs such as
Saronikos Gulf, Greece (Sklivagou et al., 2008); the coastal area off Barcelona, Spain (Tolosa et al., 1996); the Danube estuary, Black Sea (Readman et al., 2002; Wakeham, 1996); and the coastal area off Alexandria, Egypt (Aboul-Kassim and Simoneit, 1995).

Total sedimentary PAH concentrations are also significantly lower than those reported for surface sediments in coastal/estuarine areas in the Mediterranean Sea and worldwide receiving enhanced anthropogenic inputs (e.g., Bouloubassi et al., 2012; Cardellicchio et al., 2007; Lipiatou and Saliot, 1991; Sklivagou et al., 2008; Tolosa et al., 1996; Witt, 1995). They are also lower than concentrations found in deep-sea settings such as the Black Sea (Wakeham, 1996), Cap Ferret Canyon/Atlantic Ocean (OSPAR QRS, 2000) and the Arctic Ocean (Yunker et al., 2011). They rather fall within the range found in the Cretan Sea (Gogou et al., 2000) and in deep-sea settings in the northwestern Mediterranean Sea (Tolosa et al., 1996), the central Pacific Ocean (Ohkouchi et al., 1999) and the South China Sea (Yang, 2000).

\subsection{Sources of aliphatic and polycyclic aromatic hydrocarbons}

The composition and concentrations of aliphatic and polycyclic aromatic hydrocarbons reflect a mixed contribution from both natural and anthropogenic sources in deep EMS sediments. However, differences in physico-chemical properties and particle associations of individual hydrocarbons affect their dispersion pathways, their relative stability in the marine environment and preservation in marine sediments, 

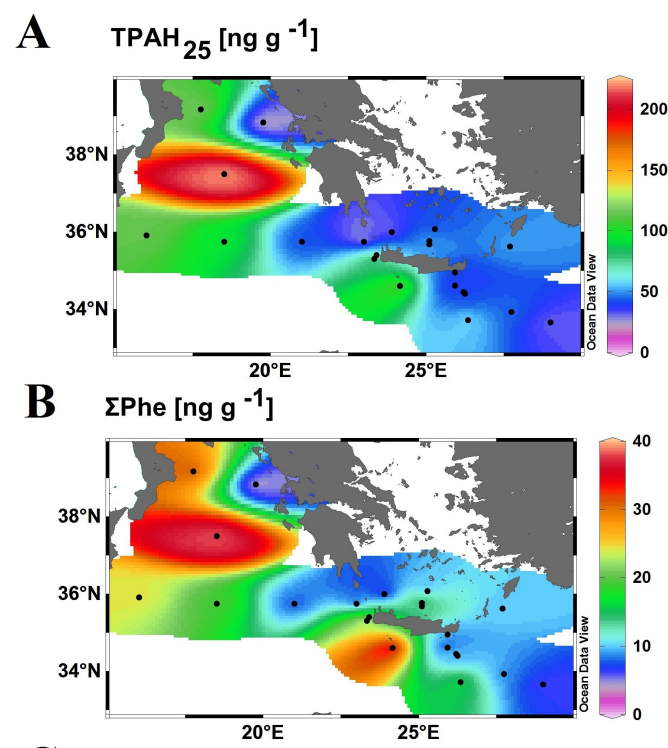

C гсомB $\left[\mathrm{ng} \mathrm{g}^{-1}\right]$

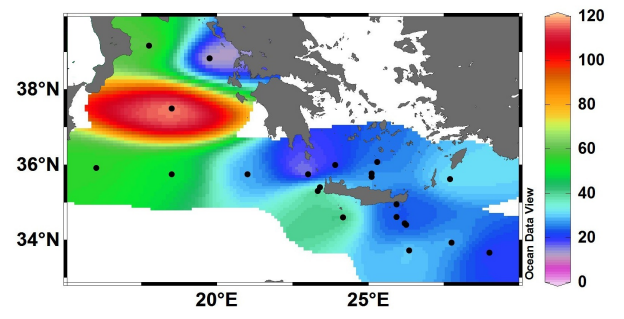

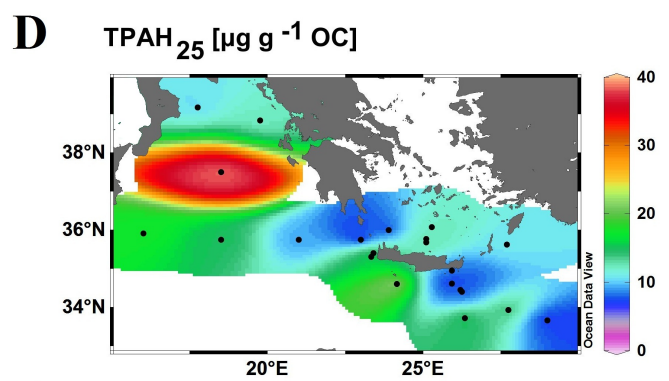

E $\quad \Sigma P h e\left[\mathrm{ug} \mathrm{g}^{-1}\right.$ OC]

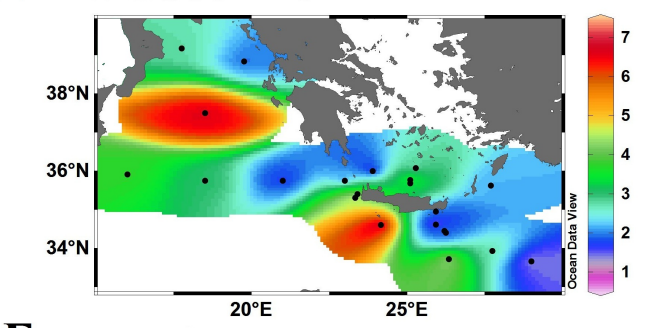

F $\quad \Sigma$ сомв $\left[\mu \mathrm{g} \mathrm{g}^{-1} \mathrm{OC}\right]$

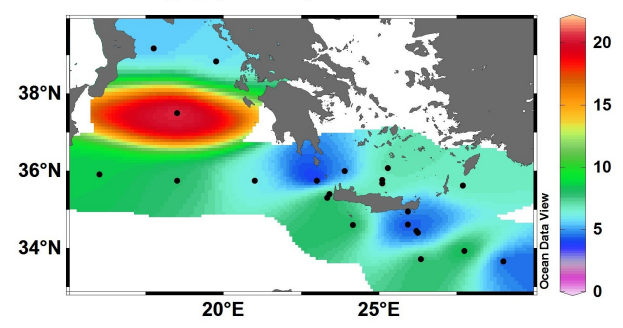

Fig. 4. Spatial contour maps of $\mathrm{TPAH}_{25}, \sum \mathrm{Phe}$ and $\sum \mathrm{COMB}$ absolute (per dry weight) and their OC-normalized concentrations in deep-sea sediments across the eastern Mediterranean Sea. $\mathrm{TPAH}_{25}, \sum$ Phe and $\sum \mathrm{COMB}$ are defined in the text.

and thus should be considered when interpreting hydrocarbon profile characteristics.

\subsubsection{Natural sources}

Natural inputs in deep EMS surficial sediments are of dominant terrestrial origin as evidenced by the pattern of $\mathrm{C}_{24}-\mathrm{C}_{35}$ $n$-alkanes with elevated odd/even carbon preference (Fig. 2a, Table 2) characteristic of epicuticular plant waxes (Eglinton and Hamilton, 1967). The sum of major terrestrial $n$ alkanes ( $n-\mathrm{C}_{27}, n-\mathrm{C}_{29}, n-\mathrm{C}_{31}$ and $\left.n-\mathrm{C}_{33}\right)$, referred to hereafter as Ter.NA, averaged $50 \%$ of total NA (Table 2), showing the importance of natural terrestrial inputs throughout the study area. Terrestrial plant $n$-alkanes are major components of eastern Mediterranean aerosols (Gogou et al., 1996), with the latter constituting major vehicles for the transport of terrestrial organic matter in deep-sea sediments of the EMS (Gogou et al., 2000; Gogou and Stephanou, 2004) due to the minor influence from riverine inputs (see Sect. 2).

The low abundance of $\mathrm{C}_{15}, \mathrm{C}_{17}$ and $\mathrm{C}_{19} n$-alkanes ( $<5 \%$ of NA) reflects a minor contribution from marine (planktonic) sources in the study area. This is consistent with the overall ultra-oligotrophic character of the eastern Mediterranean Sea (Krom et al., 2003) and the labile character of short-chain planktonic hydrocarbons, relative to the refractory long-chain terrestrial $n$-alkanes, which may also contribute to enhancement of terrestrial fingerprints (Prahl and Carpenter, 1984; Prahl et al., 1997). Bacterial sources, evidenced by the presence of hopenes (hop-17(21)-ene, hop13(18)-ene and 17 $\beta(\mathrm{H})$-hop-22(29)-ene, Fig. 5), are also of minor importance.

Regarding PAHs, the presence of retene (7-Isopropyl1-methylphenanthrene) also reflects inputs from terrestrial plants, mainly conifers (Wakeham et al., 1980) or inputs related to pinewood combustion (Ramdahl, 1983). However, retene represented less that $4 \%$ of $\mathrm{TPAH}_{25}$ in all stations, except station $\mathrm{H} 05$ in which it accounted for $\sim 18 \%$ of total PAHs (see also Sect. 5.3).

\subsubsection{Anthropogenic sources}

Amongst aliphatic hydrocarbons, a series of $\mathrm{C}_{27}-\mathrm{C}_{35}$ hopanes, a commonly used persistent geochemical indicator of oil pollution even in highly weathered oils (Wang et al., 1999), was identified in all samples (Fig. 5) exhibiting a dominant thermodynamically stable $17 \alpha(\mathrm{H}), 21 \beta(\mathrm{H})$ - configuration, with $17 \beta(\mathrm{H}), 21 \alpha(\mathrm{H})$ - compounds being less prominent, while extended $\mathrm{C}_{31}-\mathrm{C}_{35}$ homologues were present as 


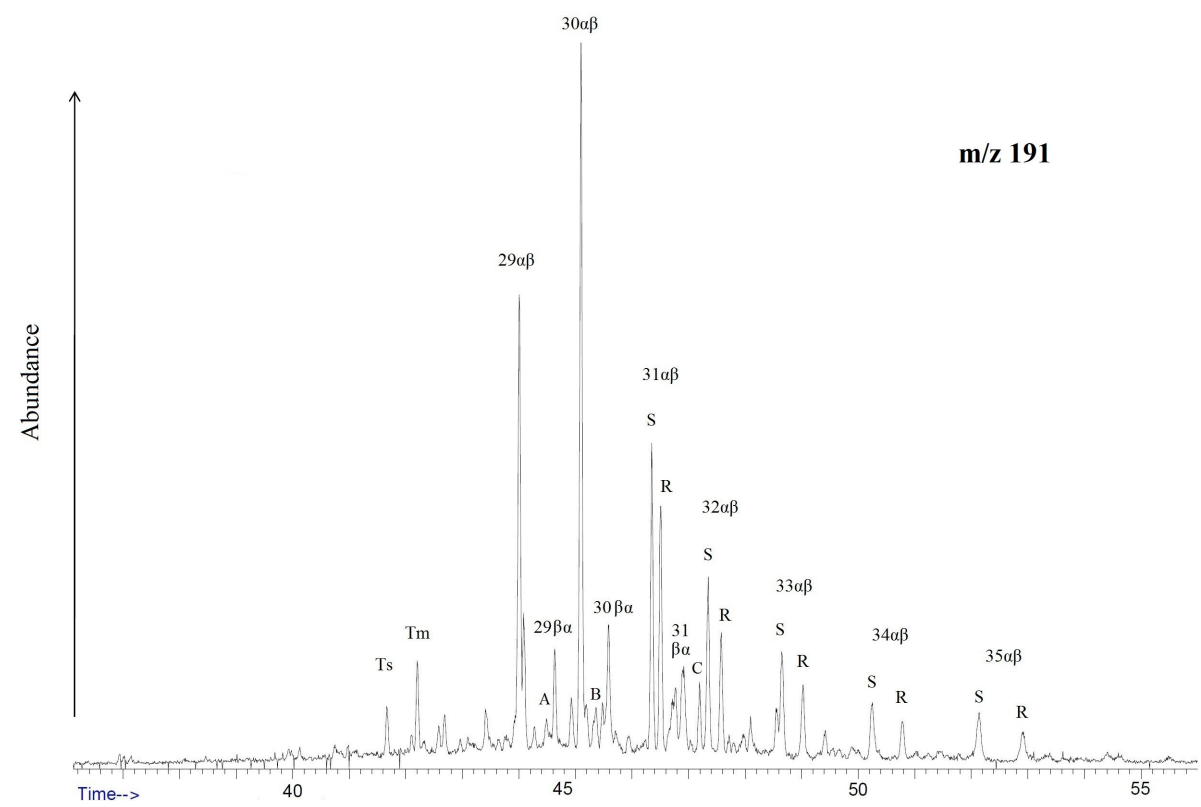

Fig. 5. Characteristic ion fragmentogram $(\mathrm{m} / z$ 191). Numerals refer to carbon numbers of hopane series; $\alpha \beta=17 \alpha(\mathrm{H}), 21 \beta(\mathrm{H})$-hopanes; $\beta \alpha=17 \beta(\mathrm{H}), 21 \alpha(\mathrm{H})$-hopanes; $\mathrm{S}$ and $\mathrm{R}=\mathrm{C}_{22} \mathrm{~S}$ and $\mathrm{R}$ configuration; Ts: $18 \alpha(\mathrm{H})-22,29,30$-trisnorneohopane; Tm: $17 \alpha(\mathrm{H})-22,29,30$ trisnorhopane; (A) hop-17(21)-ene; (B) hop-13(18)-ene; (C) 17 $\beta(\mathrm{H})$-hop-22(29)-ene (diploptene).

pairs of the $\mathrm{C}_{22}$ diastereoisomers (22S and 22R) with a $22 \mathrm{~S} / 22 \mathrm{~S}+22 \mathrm{R}$ ratio value close to 0.6 . These patterns typify oil-derived hydrocarbons (Mackenzie, 1984) indicating pollutant inputs from fossil fuel products.

The UCM recorded in all stations indicates chronic oil pollution of deep EMS sediments (Brassell and Eglinton, 1980; Farrington and Quinn, 1973). Supportive to the above, its relative abundance compared to the total resolved aliphatic hydrocarbons (TRes) $(\mathrm{UCM} / \mathrm{TRes}=3.7$ on average, Table 2) is a positive indication of contribution from degraded petroleum products (Simoneit, 1984). Aliphatic compounds of crude oil and petroleum products released in aquatic environments are subjected to degradation, with a prominent initial microbial preference for straight-chain compounds (Wang et al., 1999). This leads to the gradual removal of major compounds that can be resolved by gas chromatography and the subsequent appearance of a UCM, consisting of branched alicyclic hydrocarbons, which can persist in sediments for decades (Scarlett et al., 2007, and references therein).

The elevated abundance of NA with $\mathrm{C}_{n}>35$ at some stations points to enhanced contribution of heavy fuel oil residuals (Brooks et al., 1954; Hsieh et al., 2000), while $\mathrm{C}_{n} \leq 23$ NA without odd/even carbon preference $\left(\mathrm{CPI}_{14-23} \sim 1\right)$ likely derive from fossil inputs (light diesel, Wang et al., 1999) and/or reworked algal material (Saliot, 1981). However, the presence of the isoprenoid alkanes pristane $(\mathrm{Pr})$ and phytane $(\mathrm{Ph})$ along with the $\mathrm{C}_{n} \leq 23 \mathrm{NA}$ in corresponding stations with a ratio $\mathrm{Pr} / \mathrm{Ph}<1$ (Table 2) argues for a fossil origin of the $\mathrm{C}_{n} \leq 23 n$-alkanes.
Regarding PAHs, the dominance of alkylated homologues relative to the unsubstituted compound mainly within the phenanthrene series but also within the dibenzothiophene, pyrene and chrysene series, together with the high abundance of parent PAH with $\geq 4$ rings (Fig. 2b), reflects an admixture of PAHs deriving from both unburned fossil fuels (petroleum) and pyrolytic/combustion sources (Laflamme and Hites, 1978; Sporstøl et al., 1983; Wakeham et al., 1980).

We further applied a number of diagnostic PAH ratios proposed by Yunker et al. (2002) in order to further assess PAH sources in the study area (Table 3). However, these ratios should be considered with caution as their values may change to different extents during the environmental fate of PAHs (Tobiszewski and Namieśnik, 2012, and references therein). The Flth / (Flth + Pyr) and IndP / (IndP + BgP) ratios exhibit values $>0.50$, averaging $0.60 \pm 0.04$ and $0.56 \pm 0.02$, respectively, indicative of pyrolytic/combustion sources for these compounds (grass, wood and coal combustion). The $\mathrm{BaA} /(\mathrm{BaA}+\mathrm{Chry})$ ratio ranged between 0.15 and 0.35 (average $0.26 \pm 0.04$ ), indicating rather an admixture of both pyrolytic and fossil contributions. In the lower MW range the $\mathrm{C}_{0} /\left(\mathrm{C}_{0}+\mathrm{C}_{1}\right)$ Phe ratio ranged between 0.33 and 0.70 (average $0.51 \pm 0.10$ ), indicating varying elevated contributions of pyrolytic/ combustion (ratio $>0.5$ ) or petroleum related (ratio <0.5) phenanthrene sources in the study area. However, within the phenanthrene series the sum of $\mathrm{C}_{1^{-}}$, $\mathrm{C}_{2}$ - and $\mathrm{C}_{3}$-alkylated homologues accounted for $58-85 \%$ of $\sum$ Phe (average $72 \%$ ), indicating that even at stations where $\mathrm{C}_{0} /\left(\mathrm{C}_{0}+\mathrm{C}_{1}\right)$ Phe ratio values are $>0.5$, the large 


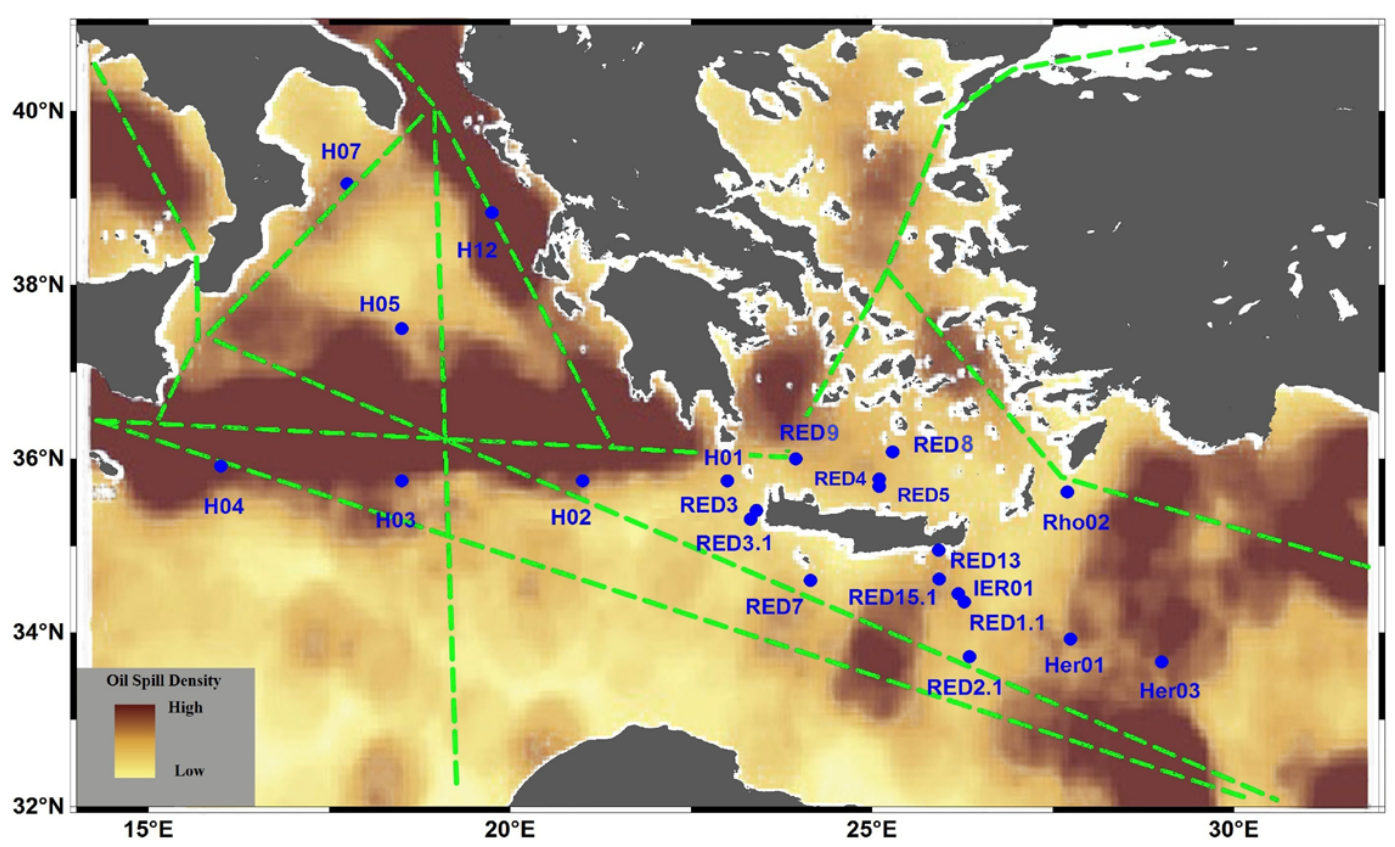

Fig. 6. Sampling sites, oil spills' normalized density reported in the study area for the years 1999-2004 (modified after Ferraro et al., 2007; reprinted from Ferraro et al., 2007, copyright (2007), with permission from Elsevier) and main EMS tanker/crude oil shipping routes (REMPEC, 2008).

proportion of determined total phenanthrenes is related to petroleum-derived alkylated homologues contribution.

The ratio of total phenanthrenes ( $\sum$ Phe) mostly derived from petrogenic inputs and $\sum$ COMB representing pyrolytic/ combustion PAHs ( $\sum$ Phe / $\sum$ COMB) ranged between 0.22 and 0.87 (Table 3), averaging $0.45 \pm 0.19$, implying that overall PAH mixtures in the study area derive from dominant pyrolytic sources. However, PAHs deriving from pyrolytic/combustion sources are strongly associated with fine combustion particles (soot and/or char black carbon) that protect them from degradation during transport from initial sources, through the water column and in sediments (Gogou et al., 1996; Simo et al., 1997; Tolosa et al., 1996; Dachs and Eisenreich, 2000; Yunker et al., 2002). In contrast, several studies have highlighted the selective degradation of low-MW labile compounds such as phenanthrene and its methyl derivatives in the marine environment (e.g., Bouloubassi et al., 2012; Simo et al., 1997; Tsapakis et al., 2003). Unlike PAHs of pyrolytic origin, these compounds enter the water column mainly through air-water diffusive exchange (Castro-Jiménez et al., 2012) or are directly introduced into surface waters following the release of petroleum products (Wang et al., 1999). Direct and indirect evidence of biodegradation has been suggested as an important factor affecting low-MW PAHs' abundance during transport in the water column (Berrojalbiz et al., 2009, 2011). Indeed, atmospheric inputs of phenanthrenes in the Mediterranean Sea are reported to be two orders of magnitude higher than settling fluxes (Castro-Jiménez et al., 2012; Dachs et al., 1997;
Deyme et al., 2011; Tsapakis et al., 2006). As a consequence, an apparent predominance of pyrolytic / combustion PAHs is commonly observed in marine sediments unless outstanding petroleum-related inputs have occurred.

Long-range atmospheric transport has been recognized as an important pathway for the introduction of both lowand high-MW PAHs and anthropogenic aliphatic hydrocarbons (e.g., UCM) across the EMS (Castro-Jiménez et al., 2012; Gogou et al., 1996; Tsapakis et al., 2003; Tsapakis and Stefanou, 2005). Concentrations of PAHs in background aerosols of the study area have been reported to be rather uniform in remote areas away from major urban centers or point sources (Castro-Jiménez et al., 2012; Tsapakis et al., 2003; Tsapakis and Stefanou, 2005). However, PAH composition of background EMS aerosols and subsequent airwater interactions are subjected to strong variability due to the interplay of several factors such as air-mass trajectory variations, deposition mode (dry/wet) and several chemical and physical processes such as gas-particle phase distributions and transformation reactions, which are often difficult to evaluate on the long-term (Tsapakis and Stefanou, 2005, 2007; see also Sect. 2). Petroleum inputs related to direct discharges from merchant shipping and / or oil transportation in the EMS have been reported to be elevated along shipping routes. Fig. 6 presents oil spills' normalized density reported for the study area regarding the year span 1999-2004 (Ferraro et al., 2007) and main EMS tanker/crude oil shipping pathways (REMPEC, 2008). 
A

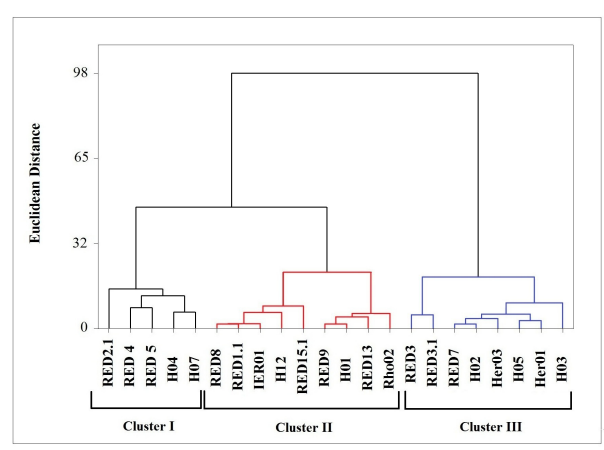

B

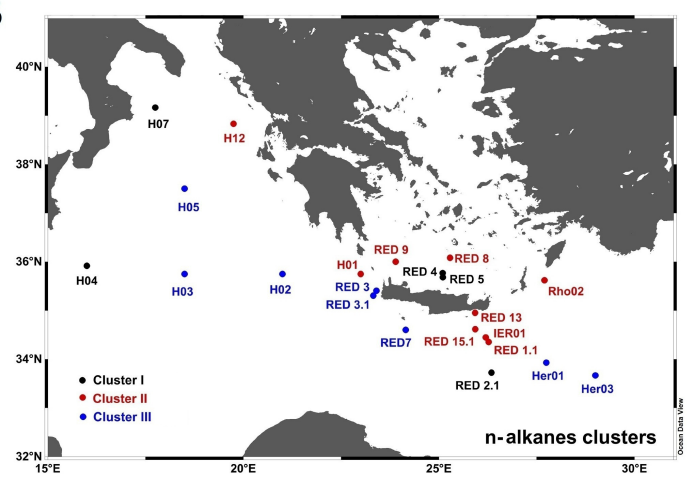

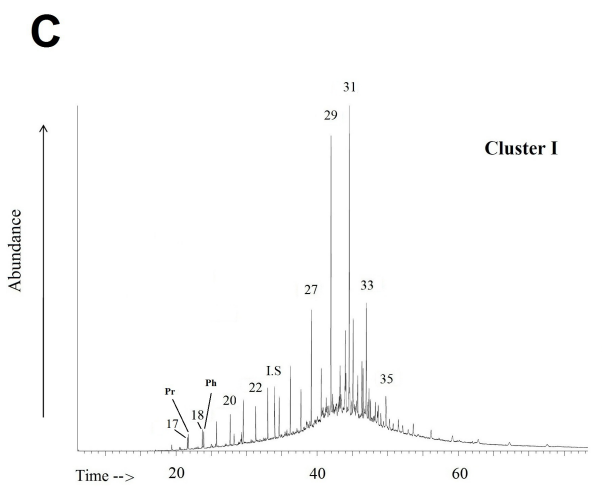
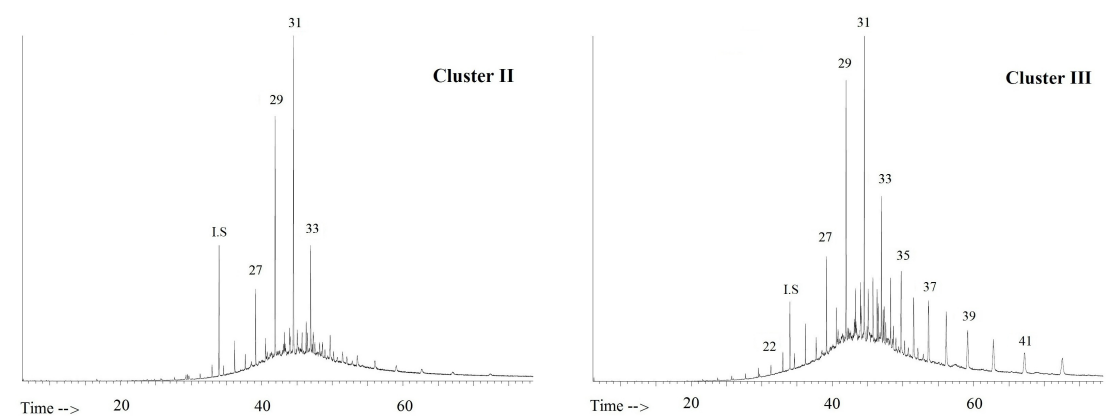

Fig. 7. Hierarchical diagram obtained from cluster analysis of stations with regard to $n$-alkane profile (A), clustered stations (B) and characteristic GC-MS traces for each returning cluster (C). NA homologues are assigned with their number of carbon atoms. Pr: pristane; Ph: phytane; I.S: internal standard.

\subsection{Regional characteristics of sedimentary aliphatic and polycyclic aromatic hydrocarbons}

Cluster analysis (joining clustering method) was applied to group stations with similar $n$-alkane or PAH profiles (see Sect. 3.2). Thus, stations are clustered into three main groups according to their $n$-alkane composition (Fig. 7). Cluster I stations (RED2.1, RED4, RED5, H04 and H07) are characterized by high abundances of Ter.NA along with low-MW homologues $\left(\mathrm{C}_{n} \leq 23\right)$. Cluster II stations (RED8, RED1.1, IER01, H12, RED15.1, RED9, H01, RED13 and Rho02) are characterized by high abundances of Ter.NA and low concentrations of both low and higher-chain NA. Stations in cluster III (RED3, RED3.1, RED7, H02, Her01, Her03, H05 and H03) are characterized by high abundances of Ter.NA along with the presence of long-chain NA homologues $\left(\mathrm{C}_{n}>35\right)$.

With regard to their $\mathrm{TPAH}_{25}$ composition characteristics, stations are also clustered into three main groups (Fig. 8). Cluster I stations (RED2.1, RED3.1, RED3, RED4, RED5, RED7, H03, H07, H04, H01, IER01 and H12) are characterized by elevated abundance of alkylated homologues within the phenanthrene, dibenzothiophene, pyrene and chrysene series, indicating enhanced relative contribution of petrogenic PAHs. Cluster II stations (RED8, RED1.1, RED13, RED9, RED15.1, H02, Her03, Her01 and Rho02) display maximum values for high-MW parent compounds along with dominance of parent phenanthrene, pyrene and chrysene, indicating predominance of pyrolytic PAHs. Finally, cluster III (station $\mathrm{H} 05$ ) is characterized by the highest concentration of retene $\left(\sim 18 \%\right.$ of $\left.\mathrm{TPAH}_{25}\right)$, a naturally derived PAH (see Sect. 5.2.1), while the low relative abundance of alkylated compounds and high contribution of $\sum$ COMB ( $>50 \%$ of $\mathrm{TPAH}_{25}$ ) indicate pyrolytic PAH predominance.

Taking into consideration the facts deriving from cluster analysis and spatial distribution of aliphatic and polycyclic aromatic hydrocarbons concentrations discussed above, the regional characteristics of hydrocarbon mixtures in the study area can be assessed. For this purpose, the ratio of total phenanthrenes to pyrolytic/combustion PAHs ( $\sum$ Phe $/ \sum \mathrm{COMB}$ ) is also depicted (Fig. 9a). The latter, varying between 0.22 and 0.87 (Table 3), allows for the assessment of fossil vs. pyrolytic/combustion PAH mixtures spatial trends (e.g., Bouloubassi et al., 2001, 2012).

\subsubsection{Ionian Sea}

Deep basins of the central Ionian Sea (stations H02, H03, H04 and H05) display the highest levels, on average, of both anthropogenic inputs and terrestrial natural inputs, reflected in both absolute and OC-normalized TAHC, UCM, Ter.NA and $\mathrm{TPAH}_{25}$ concentrations, in comparison to both northwestern Levantine deep basins and the Cretan Sea 

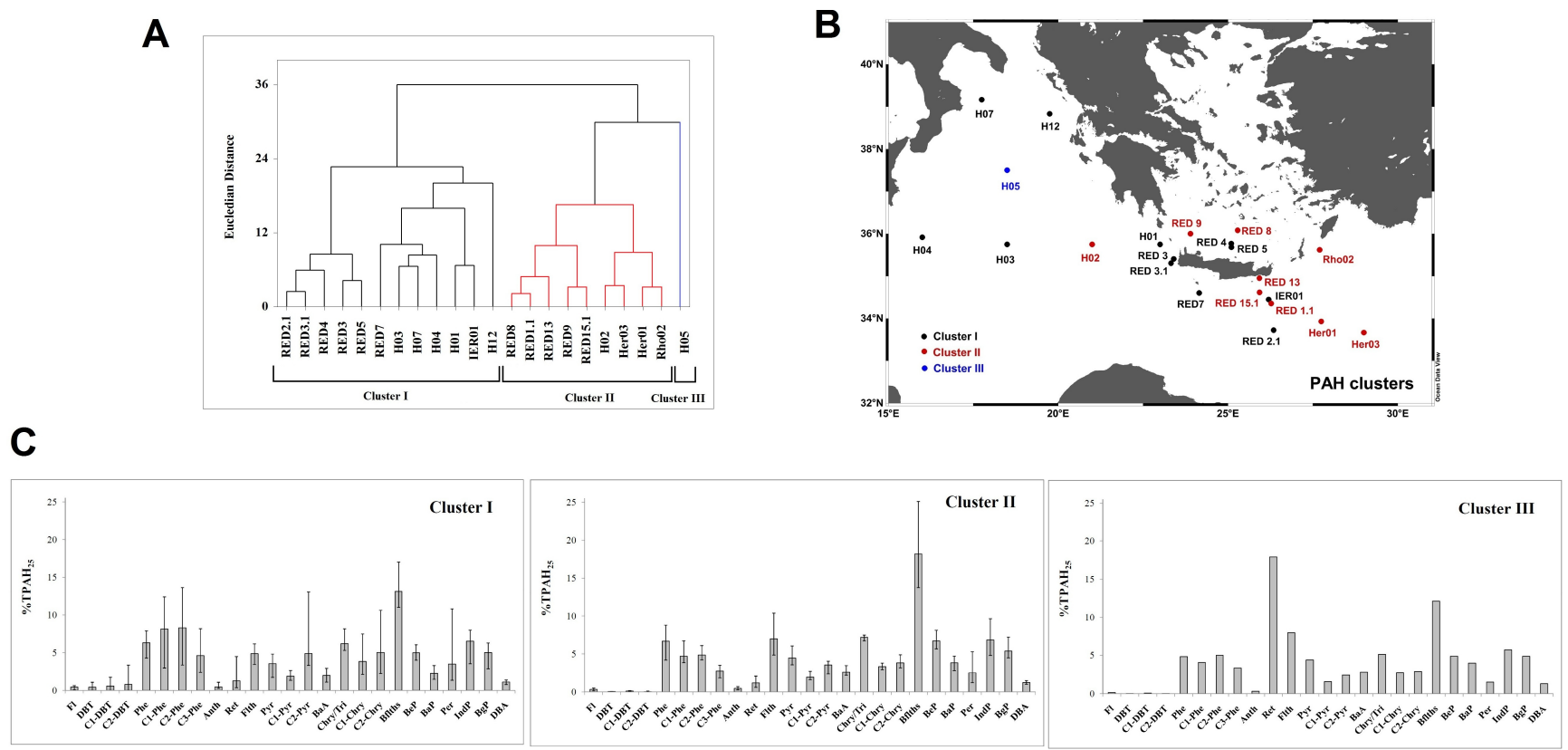

Fig. 8. Hierarchical diagram obtained from cluster analysis of stations with regard to PAH profile (A), clustered stations (B) and molecular profile for each returning cluster $(\mathbf{C})$. Individual compound abundances are normalized as percentage of $\mathrm{TPAH}_{25}$ and presented along with min-max deviation lines. PAH abbreviations are presented in Fig. 2.

(Tables 2,3; see also Sect. 4.3). High UCM and UCM / OCnormalized concentrations (maximum values at station $\mathrm{H03}$ ) indicate chronic oil pollution of surface sediments, while the elevated contribution from heavy oil residuals as inferred by $n$-alkanes with $\mathrm{C}_{n}>35$ (Fig. 7, stations $\mathrm{H} 02, \mathrm{H} 03$ and $\mathrm{H} 05$ ) and light diesel inputs (Fig. 7, station H04) is indicative of strong fossil inputs. $\sum \mathrm{Phe} / \sum \mathrm{COMB}$ and $\mathrm{C}_{0} /\left(\mathrm{C}_{0}+\mathrm{C}_{1}\right)$ Phe ratio values (Fig. 9a,b) along with PAHs profile (Fig. 8) further indicate an increase in the relative abundance of petrogenic contributions from east to west. Indeed, stations $\mathrm{H} 02$, $\mathrm{HO3}$ and $\mathrm{H} 04$ are located along the main tanker/crude oil shipping pathway from Greece to Italy, displaying a high density of oil spills, with maximum in the area around station H04 (Fig. 6).

In the northern Ionian Sea, station H07 located off the Gulf of Taranto in southern Italy lies in an area subjected to anthropogenic pressure (Cardellicchio et al., 2007). Our hydrocarbon data indicate enhanced fossil inputs, reflected in the PAHs profile, the elevated $\sum$ Phe $/ \sum$ COMB ratio values and the abundance of short-chain $n$-alkanes (Figs. 7b,c; 8b,c; 9a; Table 3). However, TAHC, $\mathrm{TPAH}_{25}$ and TAHC/OC-, $\mathrm{TPAH}_{25}$ / OC-normalized concentrations (Tables 2,3) point to a rather moderate pollutant load, while Ter.NA and Ter.NA/OC-normalized concentrations also reflect low terrestrial biogenic inputs, in comparison to the neighboring deep basins of the central Ionian Sea. Station H12 in the northeastern Ionian Sea, although located along a main shipping route from the Aegean Sea to the Adriatic Sea characterized by a high density of oil spills (Fig. 6), displays minimum values of TAHC, UCM, TPAH 25 and Ter.NA concentrations (Tables 2,3; Figs. 3,4), indicating minimum pollutant load and terrestrial contributions amongst studied sites.

\subsubsection{Cretan Sea (southern Aegean Sea) and western Cretan-Antikythera Straits}

Cretan Sea stations (RED4, RED5, RED8, RED9) display, on average, lower pollutant load and terrestrial inputs compared to the central Ionian Sea deep basins and the northwestern Levantine deep basins, as inferred from TAHC, Ter.NA, UCM, $\mathrm{TPAH}_{25}$ absolute and OC-normalized concentrations (Tables 2,3; see also Sect. 4.3). $\sum$ Phe / $\sum$ COMB ratio values (Fig. 9a, Table 3), abundance of short-chain $n$-alkanes (Fig. $7 b, c)$ and PAHs profile (Fig. 8b,c) indicate an enhanced contribution of fossil inputs at stations RED4 and RED5.

At stations located in the western Cretan-Antikythera Straits and southern Crete (H01, RED3, RED3.1 and RED7, respectively), the abundance of long-chain $n$-alkanes (Fig. 7b,c) and PAHs profile characteristics (Fig. 8b,c), along with $\sum \mathrm{Phe} / \sum \mathrm{COMB}$ and $\mathrm{C}_{0} /\left(\mathrm{C}_{0}+\mathrm{C}_{1}\right)$ Phe ratio values (Fig. 9a, b; Table 3), are indicative of strong fossil inputs in this area. Moreover, station RED3.1 located in the western Cretan Straits' canyons displays high TAHC, UCM, Ter.NA, $\mathrm{TPAH}_{25}$ absolute and OC-normalized concentrations (Tables 2,3), comparable to those found, those found in central Ionian Sea deep basins, and a twofold increase of concentrations in comparison to the neighboring RED3 located in the upper slope of the adjacent margin. Station RED7 located in 


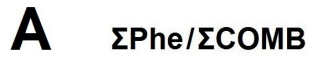

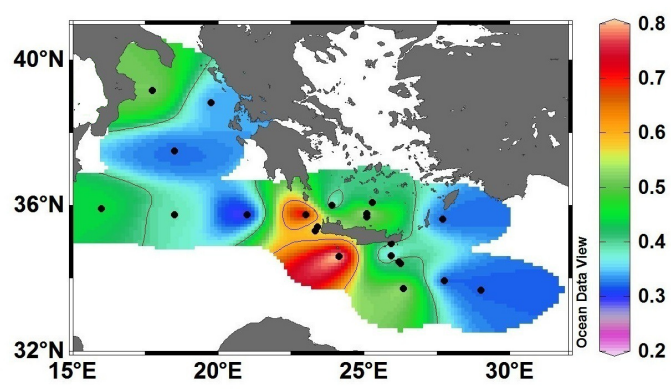

B $\quad c_{0} /\left(c_{0}+c_{1}\right) P h e$

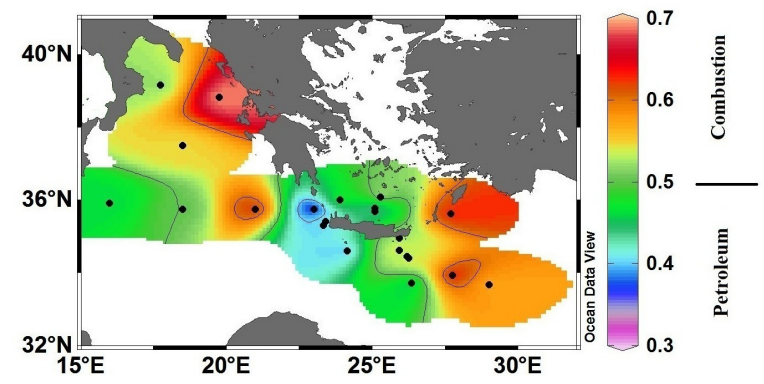

Fig. 9. Spatial distribution of the ratios $\sum \mathrm{Phe} / \sum \mathrm{COMB}(\mathbf{A})$ and $\mathrm{C}_{0} /\left(\mathrm{C}_{0}+\mathrm{C}_{1}\right)$ Phe $(\mathbf{B})$ in the study area. $(\mathbf{B})$ is presented along with literature guidelines for specific sources (Yunker et al., 2002).

southern Crete deep basins also presents high TAHC, UCM, Ter.NA and $\mathrm{TPAH}_{25}$ absolute and OC-normalized concentrations (Tables 2,3), indicating overall an elevated accumulation of both anthropogenic inputs and terrestrial natural inputs in the two aforementioned stations.

\subsubsection{Northwestern Levantine Sea}

Northwestern Levantine Sea stations (IER01, RED1.1, RED15.1, RED13, Her01, Her03 and Rho02) display rather moderate pollutant load and terrestrial natural inputs in comparison to central Ionian Sea deep basins (stations H03 and $\mathrm{H} 05$ ), reflected in both absolute and OC-normalized TAHC, UCM, Ter.NA and $\mathrm{TPAH}_{25}$ concentrations (Tables 2,3). $\sum$ Phe / $\sum$ COMB ratio values and PAHs' profile (Table 3, Fig. 8c) indicate enhanced petrogenic inputs at station IER01 located in the Ierapetra Deep in comparison to neighboring stations (RED1.1, RED15.1 and RED13). However, TAHC, $\mathrm{TPAH}_{25}$, TAHC / OC- and TPAH 25 / OC-normalized concentrations along with $n$-alkanes profile (Fig. 7b,c) for station IER01 are not indicative of a strong fossil fingerprint.

On the contrary, for station RED2.1 high levels of both anthropogenic inputs and terrestrial natural inputs, comparable to, or even higher than, those found in central Ionian Sea deep basins, reflected in both absolute and OC-normalized TAHC, UCM, Ter.NA and $\mathrm{TPAH}_{25}$ concentrations (Tables 2,3), elevated $\sum$ Phe $/ \sum$ COMB ratio values (Fig. 9a, Table 3 ), pres- ence of short-chain $n$-alkanes $\left(\mathrm{C}_{n} \leq 23\right.$, Fig. $\left.7 \mathrm{~b}, \mathrm{c}\right)$ and PAHs' profile (Fig. 8b,c) are indicative of high pollutant load, enhanced fossil inputs and high terrestrial inputs at this station, in comparison to the adjacent stations in the northwestern Levantine Sea (Her01, Her03) and around Ierapetra Deep (IER01, RED1.1, RED15.1 and RED13).

\subsection{Drivers of hydrocarbons' distribution in deep-sea sediments of the eastern Mediterranean Sea}

In order to assess the main processes driving hydrocarbons' distribution in deep-sea sediments of the study area, correlation analysis was performed for sedimentary aliphatic and polycyclic aromatic hydrocarbons concentrations (per dry weight and OC-normalized), OC content, water column depth and sedimentological parameters of collected sediments. Statistically significant correlations are presented in Table 4.

TAHC, UCM, NA, Ter.NA, TPAH $25, \sum \mathrm{COMB}$ and $\sum$ Phe concentrations show significant correlation with $\mathrm{OC}$, indicating that $\mathrm{OC}$ exerts an important control on the distribution of both natural and anthropogenic hydrocarbons in the study area. This is in agreement with earlier observations in coastal and open-sea marine sediments (Bouloubassi et al., 2012; De Luca et al., 2004; Gogou et al., 2000; Mayer, 1993; Oros and Ross, 2004; Readman et al., 2002; Tsapakis et al., 2003; Witt, 1995; Yang, 2000) and is attributed to the high affinity of hydrophobic aliphatic and polycyclic aromatic hydrocarbons to organic matter.

TAHC show higher correlation to OC than $\mathrm{TPAH}_{25}$ in terms of absolute (per dry weight) concentrations, reflected in both correlation coefficient values and level of significance, while although TAHC and $\mathrm{TPAH}_{25}$ absolute concentrations correlate significantly at the 0.01 level, TAHC / OCand $\mathrm{TPAH}_{25}$ / OC-normalized concentrations exhibit less significant correlation. The above imply that although OC exerts the main control on the distribution of both TAHC and $\mathrm{TPAH}_{25}$ in the study area, the dispersal of PAHs is probably affected by additional factors, such as the partitioning between natural $\mathrm{OC}$ and combustion-derived elemental (black) carbon that has been reported to exert major control on PAHs' distribution in sediments (Accardi-Dey and Gschwend, 2002, 2003). Consistently, TAHC/OC- and $\sum \mathrm{COMB} / \mathrm{OC}$-normalized concentrations do not exhibit any significant correlation, probably due to the fact that highMW pyrolytic / combustion PAHs ( $\sum$ COMB) show a higher affinity to elemental carbon rather than $\mathrm{OC}$ as a carrier phase (Boehm and Farrington, 1984; Gustafsson et al., 1997), while, in contrast, TAHC / OC- and $\sum$ Phe / OC-normalized concentrations are significantly correlated at the 0.01 level. This trend probably reflects the fact that low-MW phenanthrenes (mostly of fossil origin), related to the dissolved and colloidal phases in the water column, are more efficiently absorbed by organic-rich particles, e.g., phytoplankton and fecal pellets, which constitute the major vehicles for 


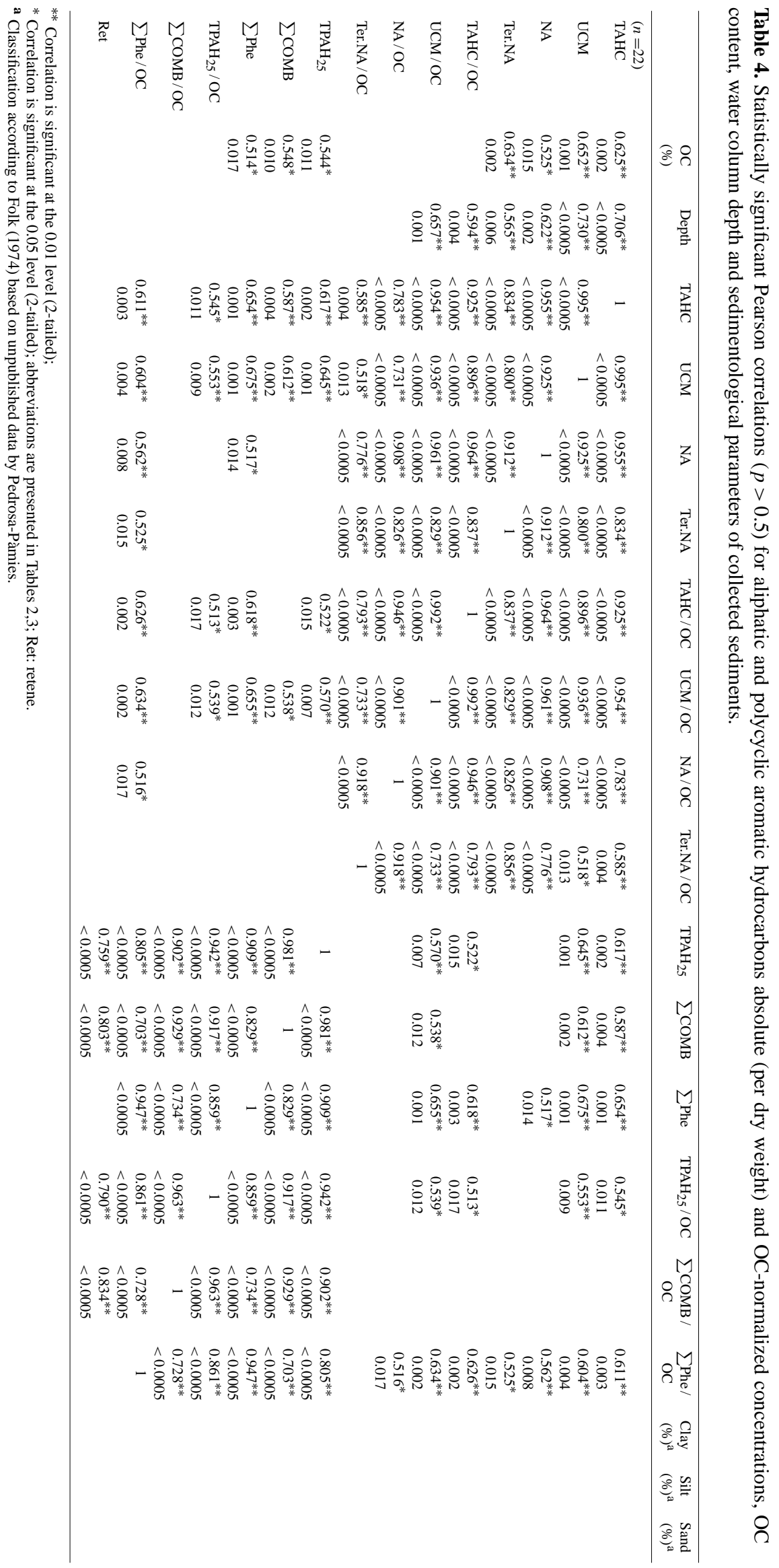


particulate OC sinking in the deep sea (Berrojalbiz et al., 2009; Bouloubassi et al., 2006; Castro-Jiménez et al., 2012; Dachs et al., 1996, 1997).

The partitioning of aliphatic and polycyclic aromatic hydrocarbons in sediments has also been related to specific grain-size properties (i.e., clays, silts and/or sands; Boehm and Farrington, 1984; Bouloubassi et al., 2012; Prahl and Carpenter, 1984). However, in our data set there is no significant correlation between aliphatic and polycyclic aromatic hydrocarbons' concentrations and grain-size characteristics of collected sediments (Table 4). This implies that hydrocarbon phase associations may not be similar amongst various source materials and/or different regions in the study area, while an overprint resulting from point sources (mainly fossil due to intense maritime traffic) could also blur potential associations, and thus should be considered. Although extreme caution should be exercised when considering interpolations in wide geographical areas, since the overall low density of available stations may not allow appreciation of occurring variations, no significant correlation between aliphatic and polycyclic aromatic hydrocarbons' concentrations and grain size was found even when limiting the data set to specific sub-regions (Ionian Sea, Cretan Sea, northwestern Levantine Sea; data not shown).

Overall, concentrations of total aliphatic hydrocarbons (TAHC) correlate with water column depth (Table 4), indicating that deep EMS basins act as their repository. However distinct trends are observed for various aliphatic components. Anthropogenic UCM concentrations (both absolute and OC-normalized) are better correlated with water column depth than terrestrial plant $n$-alkanes (Table 4), implying enhanced accumulation of fossil aliphatic hydrocarbons in deep-basin sediments relative to biogenic terrestrial ones. This is further supported by the significant correlations of $\mathrm{CPI}_{24-35}(r=-0.559 ; p=0.006)$ and UCM/TRes $(r=0.656 ; p=0.007)$ with water column depth. Several factors could explain these trends. UCM is known to be more refractory than biogenic hydrocarbons (Simoneit, 1982), while different transport pathways and/or phase associations for natural and fossil aliphatic hydrocarbons may also have impacted on their distribution and fate. Moreover, although long-range atmospheric transport constitutes a major transport pathway for both terrestrial plant and fossil $n$-alkanes in the open EMS, the latter are also directly introduced into surface waters following the release of petroleum products (see Sect. 5.2).

Regarding PAHs, the lack of correlation between $\mathrm{TPAH}_{25}$, $\sum$ COMB, $\sum$ Phe concentrations and water column depth (Table 4) could probably be attributed to the partitioning of PAHs between natural OC and combustion-derived black carbon as discussed above. However, the selective degradation of low-MW phenanthrenes and differences in transport mechanisms/phase associations of individual PAH compounds discussed in Sect. 5.2 should also be considered. Amongst PAHs, retene concentrations do not correlate with terrestrial $n$-alkanes (Ter.NA) despite their common origin, while retene does not exhibit significant correlation either with OC. However, retene correlated significantly with high-MW pyrolytic / combustion PAHs ( $\sum$ COMB), indicating an overall probable relative significant contribution from sources related to pinewood combustion rather than terrestrial plant resins.

Lack of correlation between Ter.NA and $\sum$ COMB concentrations also indicate different sources and/or transport pathways for naturally derived terrestrial $n$-alkanes and pyrolysis/combustion-derived PAHs. The above is in agreement with the fact that terrestrial $n$-alkanes are transported in aerosols, which constitute the likely major transport pathway of both Ter.NA and $\sum$ COMB in the open EMS (see Sects. 2 and 5.2), both as plant waxes and smoke from biomass burning (Bendle et al., 2007; Yunker et al., 2011), while instead pyrolysis/combustion-derived $\sum$ COMB compounds' transport and dispersal is associated with fine soot and/or char black carbon combustion particles (Yunker et al., 2002, and references therein). Finally, NA concentrations significant correlation to $\sum$ Phe could be attributed to the constituent characteristics of total $n$-alkanes, which except for Ter.NA, that account for an average of $50 \%$ of their total sum (see Sect. 5.2 and Table 2), comprise also of a large percentage of labile aliphatic compounds whose high relative abundance, as in the case of $\sum$ Phe, is likely attributed to enhanced petroleum-related inputs in specific areas.

Water masses' circulation characteristics also seem to influence regional features and distribution patterns of hydrocarbons in the study area. The low hydrocarbon content of station H12 located in the northeastern Ionian Sea, evidenced by the minimum values of TAHC, UCM, TPAH ${ }_{25}$, Ter.NA and corresponding OC-normalized concentrations (Tables 2,3; Sect. 5.3.1), is probably related to its low OC content $(0.15 \%$, Table 1$)$ as a result of strong near-bottom currents that could lead to the resuspension and dispersal of sedimentary material (Poulos et al., 1999). Indeed, station H12 is predominantly composed $(\sim 80 \%)$ of poorly sorted silt with sand-sized fraction representing $\sim 5 \%$ of the total mass (Pedrosa-Pàmies, unpublished data).

Deep Ionian Sea basins display high accumulation of both terrestrial-related natural inputs and petroleum-related anthropogenic inputs in comparison to both northwestern Levantine deep basins and Cretan Sea (Tables 2,3; Sects. 4.3 and 5.3.1). The renewal time of the Ionian deep and bottom waters is approximately $58 \mathrm{yr}$ (Schlitzer et al., 1991), and thus deep Ionian Sea basins may act as a long-term repository of hydrocarbons exported from the Adriatic Sea, since the latter is their main deep-water source (see Sect. 2). Supportive to the above, stations H05 and H03 located along the outflow of deep Adriatic waters in the Ionian Sea present elevated Ter.NA and TAHC absolute and OC-normalized concentrations (Table 2) with an increasing trend from the shallower H05 to the deeper station H03, while station H05 also 


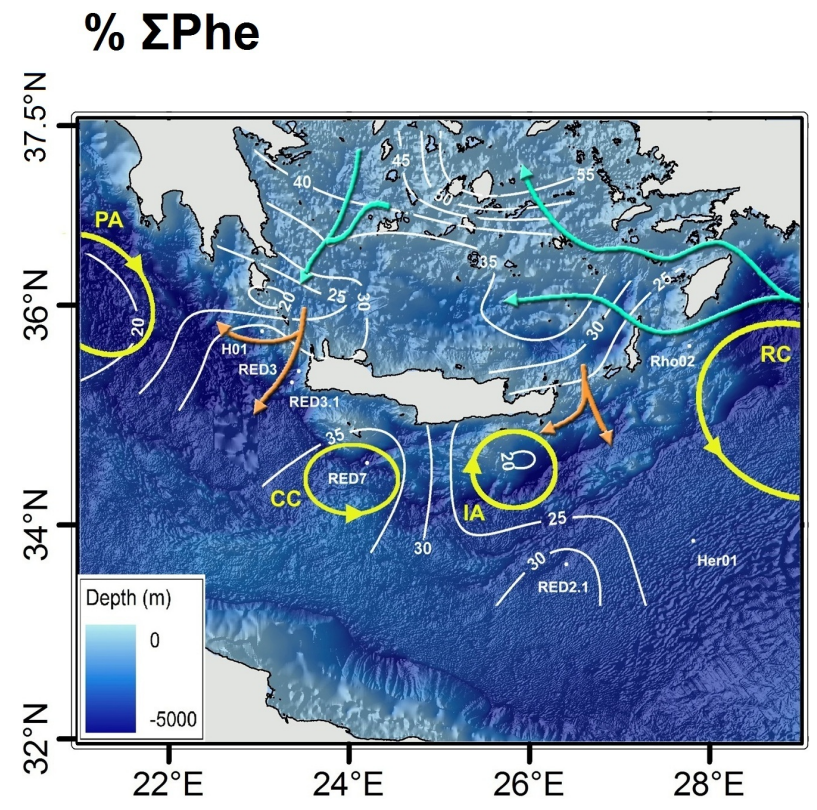

Fig. 10. Spatial contour map of $\% \sum$ Phe contribution in the central Aegean Sea, Cretan Sea (southern Aegean Sea), western CretanAntikythera Straits and northwestern Levantine surface sediments. Data regarding central Aegean Sea sediments are reported by Hatzianestis and Sklivagou (2001), data regarding Cretan Sea sediments are a combination of data reported in this study and data reported by Hatzianestis and Sklivagou (2001), while data regarding northwestern Levantine sediments are reported in this study. $\sum \mathrm{Phe}$ sum includes $\mathrm{Phe}, \mathrm{C}_{1}$-Phe and $\mathrm{C}_{2}$-Phe, while $\% \sum \mathrm{Phe}$ is calculated on the basis of $15 \mathrm{PAH}$ compounds common for Hatzianestis and Sklivagou (2001) and this study, i.e., Phe, $\mathrm{C}_{1}$-Phe, $\mathrm{C}_{2}$-Phe, Anth, Flth, Pyr, BaA, Chry, BFlths, BeP, BaP, Per, IndP, BgP and DBA (PAH abbreviations are presented in Fig. 2); RC: Rhodes cyclone; IA: Ierapetra anticyclone; CC: Cretan cyclone; PA: Pelops anticyclone; orange lines: Cretan intermediate/deep-waters outflow; cyan lines: Aegean Sea surface waters pathways. Bathymetric data were produced using the GEBCO Digital Atlas (IOC, IHO and BODC, 2003).

presents high relative abundance of retene, a naturally derived PAH (see Sect. 5.2.1 and cluster analysis of PAHs).

As discussed in Sect. 5.3.2, stations located in the western Cretan-Antikythera Straits and southern Crete display strong fossil inputs, while stations RED4 and RED5 in the Cretan Sea also display an enhanced fossil signature (Fig. 9a). Hatzianestis and Sklivagou (2001) have reported a significantly high contribution of $\sum$ Phe in central Aegean Sea surface sediments ( $>60 \%$ of total PAHs determined), which is attributed to outstanding petroleum-related inputs, followed by an elevated contribution of $\sum$ Phe in the southern Aegean Sea (Cretan Sea) surface sediments. These data combined with results reported in this study (Fig. 10) evidence a decreasing southward trend for sedimentary $\% \sum$ Phe contribution from the central Aegean Sea to the Cretan Sea and western Cretan-Antikythera Straits.
This trend could be attributed to water masses' circulation patterns of the Aegean Sea and mesoscale activity at the Cretan Straits exit, along with chemical characteristics of lowMW petrogenic PAHs. The latter, entering the water column through air-water diffusive exchange or directly into surface waters following the release of petroleum products, occur mainly in the dissolved phase, and thus display longer residence time in the water column prior to their settling, leading to a potential subjection to long-distance transport. The general cyclonic circulation of the Aegean Sea results in an almost constant net outflow, in the upper $400 \mathrm{~m}$ of depth, towards the EMS observed in the western Cretan Straits (Kontoyiannis et al., 1999, 2005). Surface water masses are also transformed during winter in the central Aegean Sea (and the Cyclades Plateau) into denser intermediate water which then fills the Cretan Basin, finally outflowing to the EMS through the Cretan Straits (Gertman et al., 2006). This transfer may be also be enhanced during periods of deep-water formation in the Aegean Sea, when dense water outflows through the eastern and western Cretan Straits' canyons (Lykousis et al., 2011). Moreover, water masses exiting the Cretan Straits are subject to the influence of permanent/transient mesoscale gyres presented in Fig. 10. The above likely contribute to the southward transfer of petrogenic PAHs introduced into surface waters of the central Aegean Sea, comprising an important advective source of fossil-related PAHs for waters of the southern Aegean Sea and western Cretan-Antikythera Straits, with elevated inputs also reflected, following their subsequent settling, in their increased relative abundance in surface sediments.

In this procedure, the western Cretan Straits' canyons and southern Crete deep basins (stations RED3.1 and RED7) seem to represent a significant sink for hydrocarbons, reflected in the almost twofold elevated values of TAHC, UCM, NA and $\mathrm{TPAH}_{25}$ concentrations (Tables 2,3; Sect. 5.3.2), in agreement with earlier observations regarding the transfer and distribution of organic pollutants in deepcanyon settings (Bouloubassi et al., 2012; Dachs et al., 1997; Fang et al., 2009; Salvadó et al., 2012). The fact that the station located within the canyons (RED3.1) shows an approximately twofold increase in OC content compared to the neighboring station (RED3) located in the upper slope of the adjacent margin (Table 1) is in agreement with earlier observations of fine-grained and OC-rich sediment transfer in the western Cretan Straits' canyons (Kerhervé et al., 1999; Pusceddu et al., 2010). Indeed, station RED3.1, and also RED7 in southern Crete, are mainly composed of silt and clay fractions (Pedrosa-Pàmies, unpublished data) that likely exert an important control on the enhanced accumulation of TAHC, UCM, NA, TPAH 25 , but also Ter.NA, reflected in their elevated OC-normalized concentrations in these stations (Tables 2,3; Sect. 4.3), in agreement with earlier reports on the preferential partitioning/accumulation of aliphatic and polycyclic aromatic hydrocarbons in fine-grained sediment 
fractions (Boehm and Farrington, 1984; Bouloubassi et al., 2012; Prahl and Carpenter, 1984).

\section{Conclusions}

Aliphatic and polycyclic aromatic hydrocarbons' profile characteristics, source-specific molecular markers and their diagnostic indices reveal mixed contributions from both natural and anthropogenic compounds accumulating in deep-sea surface sediments of the eastern Mediterranean Sea (EMS). Natural hydrocarbons derive from both autochthonous marine (planktonic and bacterial inputs) and allochthonous (terrestrial vegetation, mainly higher plant waxes) sources, with the terrestrial fingerprint being the predominant one, probably due to the ultra-oligotrophic character of the eastern Mediterranean and the labile character of the marinederived short-chain hydrocarbons. Anthropogenic inputs are reflected by PAHs of pyrolytic origin, related mainly to atmospheric inputs, and by fossil compounds both atmospherically derived and from intense maritime activities in the EMS, with the latter resulting in chronic oil pollution of surface sediments, as evidenced by the persistence of unresolved hydrocarbon mixture in all sampling sites.

Determined aliphatic and polycyclic aromatic hydrocarbons in the study area occur at levels comparable to those reported for open marine sites of the western Mediterranean Sea and worldwide, receiving low anthropogenic inputs. Amongst the deep EMS basins, the central Ionian Sea displays elevated levels of both anthropogenic and natural inputs, followed by deep basins of the northwestern Levantine and Cretan seas. Concentrations of both aliphatic and polycyclic aromatic hydrocarbons exhibit significant correlation with $\mathrm{OC}$ contents, indicating that the latter exerts a main control on their transport, fate and ultimate accumulation in deep EMS basins. However, the composition of hydrocarbon mixtures display significant regional variability, reflecting the relative importance of sources and differences in transport pathways and/or phase associations of biogenic terrestrial hydrocarbons and anthropogenic fossil and pyrolysis/combustion-derived hydrocarbons, which impact on their overall distribution and fate. Circulation patterns also seem to influence hydrocarbons' regional features and distribution patterns, likely comprising an important advective source for fossil-related PAHs from the central Aegean Sea to the southern Aegean Sea and, subsequently, to the western Cretan-Antikythera Straits.

Major findings of this study highlight the role of deep EMS basins as repositories of both natural and anthropogenic hydrocarbons, while fine-grained and OC-rich sediment transfer likely exerts an important control on the enhanced accumulation of aliphatic and polycyclic aromatic hydrocarbons in the western Cretan Straits' canyons and the southern Crete deep basins.
Acknowledgements. This work has been supported by the HERMIONE IP (EU/FP7), MEDECOS and REDECO (MarinERA, EU/FP6) projects and a grant by Generalitat de Catalunya to the University of Barcelona (2009 SGR 1305). We sincerely thank chief scientists K.-C. Emeis and N. Lampadariou and the officers and crews of R/V Aegaeo (Hellenic Centre for Marine Research, Greece) and R/V Meteor (University of Hamburg, Germany) for their precious help during cruises, and Chara Kyriakidou (HCMR, Athens) for preparation of the study area map. We would also like to thank the two anonymous reviewers for their helpful and constructive comments, which greatly helped us improve our manuscript.

Edited by: R. Danovaro

\section{References}

Aboul-Kassim, T. A. T. and Simoneit, B. R. T.: Petroleum hydrocarbon fingerprinting and sediment transport assessed by molecular biomarker and multivariate statistical analyses in the Eastern Harbour of Alexandria, Egypt, Mar. Pollut. Bull., 30, 63-73, doi:10.1016/0025-326x(94)00102-f, 1995.

Accardi-Dey, A. and Gschwend, P. M.: Assessing the combined roles of natural organic matter and black carbon as sorbents in sediments, Environ. Sci. Technol., 36, 21-29, doi:10.1021/es010953c, 2002.

Accardi-Dey, A. and Gschwend, P. M.: Reinterpreting literature sorption data considering both absorption into organic carbon and adsorption onto black carbon, Environ. Sci. Technol., 37, 99106, doi:10.1021/es020569v, 2003.

Alebic-Juretic, A.: Polycyclic aromatic hydrocarbons in marine sediments from the Rijeka Bay area, Northern Adriatic, Croatia, 1998-2006, Mar. Pollut. Bull., 62, 863-869, doi:10.1016/j.marpolbul.2011.01.035, 2011.

Bendle, J., Kawamura, K., Yamazaki, K., and Niwai, T.: Latitudinal distribution of terrestrial lipid biomarkers and n-alkane compound-specific stable carbon isotope ratios in the atmosphere over the western Pacific and Southern Ocean, Geochim. Cosmochim. Ac., 71, 5934-5955, doi:10.1016/j.gca.2007.09.029, 2007.

Berrojalbiz, N., Lacorte, S., Calbet, A., Saiz, E., Barata, C., and Dachs, J.: Accumulation and cycling of polycyclic aromatic hydrocarbons in zooplankton, Environ. Sci. Technol., 43, 22952301, doi:10.1021/es8018226, 2009.

Berrojalbiz, N., Dachs, J., Ojeda, M. J., Valle, M. C., CastroJiménez, J., Wollgast, J., Ghiani, M., Hanke, G., and Zaldivar, J. M.: Biogeochemical and physical controls on concentrations of polycyclic aromatic hydrocarbons in water and plankton of the Mediterranean and Black Seas, Global Biogeochem. Cy., 25, GB4003, doi:10.1029/2010gb003775, 2011.

Boehm, P. D. and Farrington, J. W.: Aspects of the polycyclic aromatic hydrocarbon geochemistry of recent sediments in the Georges Bank Region, Environ. Sci. Technol., 18, 840-845, 1984.

Botsou, F. and Hatzianestis, I.: Polycyclic aromatic hydrocarbons (PAHs) in marine sediments of the Hellenic coastal zone, eastern Mediterranean: Levels, sources and toxicological significance, J. Soil. Sediment., 12, 265-277, doi:10.1007/s11368-011-0453-1, 2012. 
Bouloubassi, I., Lipiatou, E., Saliot, A., Tolosa, I., Bayona, J. M., and Albaiges, J.: Carbon sources and cycle in the western Mediterranean - The use of molecular markers to determine the origin of organic matter, Deep-Sea Res. Pt. II, 44, 781-799, doi:10.1016/s0967-0645(96)00094-x, 1997.

Bouloubassi, I., Fillaux, J., and Saliot, A.: Hydrocarbons in surface sediments from there Changjiang (Yangtze River) Estuary, East China Sea, Mar. Pollut. Bull., 42, 1335-1346, doi:10.1016/s0025-326x(01)00149-7, 2001.

Bouloubassi, I., Méjanelle, L., Pete, R., Fillaux, J., Lorre, A., and Point, V.: PAH transport by sinking particles in the open Mediterranean Sea: A 1 year sediment trap study, Mar. Pollut. Bull., 52, 560-571, doi:10.1016/j.marpolbul.2005.10.003, 2006.

Bouloubassi, I., Roussiez, V., Azzoug, M., and Lorre, A.: Sources, dispersal pathways and mass budget of sedimentary polycyclic aromatic hydrocarbons (PAH) in the NW Mediterranean margin, Gulf of Lions, Mar. Chem., 142, 18-28, doi:10.1016/j.marchem.2012.07.003, 2012.

Brassell, S. C., Eglinton, G., Maxwell, J. R., and Philp, R. P.: Natural background of alkanes in the aquatic environment, in: Aquatic Pollutants: Transformation and Biological Effects, edited by: Hutzinger, O., van Lelyveld I. H., and Zoetman B. C. J., Pergamon Press, Oxford, 69-86, 1978.

Brassell, S. C., and Eglinton, G.: Environmental chemistry - an interdisciplinary subject, Natural and pollutant organic compounds in contemporary aquatic environments, in: Analytical Techniques in Environmental Chemistry, edited by: Albaiges, J., Pergamon, Oxford, 1980.

Brooks, B. T., Kurtz, S. S., Boord, C. E., and Schmerling, L. (Eds): The Chemistry of Petroleum Hydrocarbons. Vol. 1, Chapt. 3, Reinhold Publishing Corp., New York, 1954.

Cabrerizo, A., Dachs, J., Moeckel, C., Ojeda, M. J., Caballero, G., Barceló, D., and Jones, K. C.: Ubiquitous net volatilization of polycyclic aromatic hydrocarbons from soils and parameters influencing their soil-air partitioning, Environ. Sci. Technol., 4740-4747, doi:10.1021/es104131f45, 2011.

Cardellicchio, N., Buccolieri, A., Giandomenico, S., Lopez, L., Pizzulli, F., and Spada, L.: Organic pollutants (PAHs, PCBs) in sediments from the Mar Piccolo in Taranto (Ionian Sea, Southern Italy), Mar. Pollut. Bull., 55, 451-458, doi:10.1016/j.marpolbul.2007.09.007, 2007.

Castro-Jiménez, J., Berrojalbiz, N., Wollgast, J., and Dachs, J.: Polycyclic aromatic hydrocarbons (PAHs) in the Mediterranean Sea: Atmospheric occurrence, deposition and decoupling with settling fluxes in the water column, Environ. Pollut., 166, 40-47, doi:10.1016/j.envpol.2012.03.003, 2012.

Dachs, J. and Eisenreich, S. J.: Adsorption onto aerosol soot carbon dominates gas-particle partitioning of polycyclic aromatic hydrocarbons, Environ. Sci. Technol., 34, 3690-3697, doi:10.1021/es991201, 2000.

Dachs, J., Bayona, J. M., Fowler, S. W., Miquel, J. C., and Albaigés, J.: Vertical fluxes of polycyclic aromatic hydrocarbons and organochlorine compounds in the western Alboran Sea (southwestern Mediterranean), Mar. Chem., 52, 75-86, 1996.

Dachs, J., Bayona, J. M., Raoux, C., and Albaiges, J.: Spatial, vertical distribution and budget of polycyclic aromatic hydrocarbons in the Western Mediterranean seawater, Environ. Sci. Technol., 31, 682-688, 1997.
Dachs, J., Lohmann, R., Ockenden, W. A., Méjanelle, L., Eisenreich, S. J., and Jones, K. C.: Oceanic biogeochemical controls on global dynamics of persistent organic pollutants, Environ. Sci. Technol., 36, 4229-4237, doi:10.1021/es025724k, 2002.

De Luca, G., Furesi, A., Leardi, R., Micera, G., Panzanelli, A., Costantina Piu, P., and Sanna, G.: Polycyclic aromatic hydrocarbons assessment in the sediments of the Porto Torres Harbor (Northern Sardinia, Italy), Mar. Chem., 86, 15-32, doi:10.1016/j.marchem.2003.11.001, 2004.

Deyme, R., Bouloubassi, I., Taphanel-Valt, M. H., Miquel, J. C., Lorre, A., Marty, J. C., and Méjanelle, L.: Vertical fluxes of aromatic and aliphatic hydrocarbons in the Northwestern Mediterranean Sea, Environ. Pollut., 159, 3681-3691, 10.1016/j.envpol.2011.07.017, 2011.

Eglinton, G. and Hamilton, R. J.: Leaf epicuticular waxes, Science, 156, 1322-1335, 1967.

European Environment Agency: Priority Issues in the Mediterranean Environment, EEA Report no. 4, EEA, Copenhagen, 2006.

Fang, M. D., Chang, W. K., Lee, C. L., and Liu, J. T.: The use of polycyclic aromatic hydrocarbons as a particulate tracer in the water column of Gaoping (Kaoping) Submarine Canyon, J. Marine Syst., 76, 457-467, doi:10.1016/j.jmarsys.2007.08.004, 2009.

Farrington J.W. and Quinn, J. G.: Petroleum hydrocarbons in Narragansett Bay: I. Survey of hydrocarbons in sediments and clams (Mercenaria mercenaria), Estuar. Coast. Mar. Sci., 1, 71-79, 1973.

Ferraro, G., Bernardini, A., David, M., Meyer-Roux, S., Muellenhoff, O., Perkovic, M., Tarchi, D., and Topouzelis, K.: Towards an operational use of space imagery for oil pollution monitoring in the Mediterranean basin: A demonstration in the Adriatic Sea, Mar. Poll. Bull., 54, 403-422, doi:10.1016/j.marpolbul.2006.11.022, 2007.

Folk, R. L.: Petrology of sedimentary rocks, Hemphill, Austin, Texas, 1974.

Garcia-Orellana, J., Pates, J. M., Masqué, P., Bruach, J. M., and Sanchez-Cabeza, J. A.: Distribution of artificial radionuclides in deep sediments of the Mediterranean Sea, Sci. Total Environ., 407, 887-898, doi:10.1016/j.scitotenv.2008.09.018, 2009.

Gertman, I., Pinardi, N., Popov, Y., and Hecht, A.: Aegean sea water masses during the early stages of the Eastern Mediterranean Climatic Transient (1988-90), J. Phys. Oceanogr., 36, 1841-1859, doi:10.1029/2003JC001778, 2006.

Gogou, A. and Stephanou, E. G.: Marine organic geochemistry of the Eastern Mediterranean: 2. Polar biomarkers in Cretan Sea surficial sediments, Mar. Chem., 85, 1-25, 2004.

Gogou, A., Stratigakis, N., Kanakidou, M., and Stephanou, E. G.: Organic aerosols in Eastern Mediterranean: components source reconciliation by using molecular markers and atmospheric back trajectories, Org. Geochem., 25, 79-96, doi:10.1016/s01466380(96)00105-2, 1996.

Gogou, A. I., Apostolaki, M., and Stephanou, E. G.: Determination of organic molecular markers in marine aerosols and sediments: one-step flash chromatography compound class fractionation and capillary gas chromatographic analysis, J. Chromatogr. A, 799, 215-231, doi:10.1016/s0021-9673(97)01106-0, 1998.

Gogou, A., Bouloubassi, I., and Stephanou, E. G.: Marine organic geochemistry of the Eastern Mediterranean: 1. Aliphatic and 
polyaromatic hydrocarbons in Cretan Sea surficial sediments, Mar. Chem., 68, 265-282, doi:10.1016/s0304-4203(99)00082-1, 2000.

Gonul, L. T. and Kucuksezgin, F.: Aliphatic and polycyclic aromatic hydrocarbons in the surface sediments from the Eastern Aegean: assessment and source recognition of petroleum hydrocarbons, Environ. Sci. Pollut. R., 19, 31-41, doi:10.1007/s11356-0110524-2, 2012.

Gough, M. A. and Rowland, S. J.: Characterization of unresolved complex mixtures of hydrocarbons in petroleum, Nature, 344, 648-650, 1990.

Gustafsson, Ö., Haghseta, F., Chan, C., Macfarlane, J., and Gschwend, P. M.: Quantification of the dilute sedimentary soot phase: Implications for PAH speciation and bioavailability, Environ. Sci. Technol., 31, 203-209, doi:10.1021/es960317s, 1997.

Guzzella, L. and De Paolis, A.: Polycyclic aromatic hydrocarbons in sediments of the Adriatic Sea, Mar. Pollut. Bull. 28, 159-165, doi:10.1016/0025-326x(94)90392-1, 1994.

Hatzianestis, I. and Sklivagou, E.: Distribution of Polycyclic Aromatic Hydrocarbons in surface sediments of the Aegean Sea (Eastern Mediterranean), presented at the 7th Greece-Cyprus chemistry conference, Nikosia, 55-59, 2001.

Hatzianestis, J., Sklivagou, E., and Friligos, N.: Hydrocarbons in surface sediments from the northern Aegean Sea, Rapp. Comm. Int. Mer. Medit., 35, 264-265, 1998.

Hsieh, M., Philp, R. P., and Del Rio, J. C.: Characterization of high molecular weight biomarkers in crude oils, Org. Geochem., 31, 1581-1588, doi:10.1016/s0146-6380(00)00085-1, 2000.

IOC, IHO, and BODC: Centenary Edition of the GEBCO Digital Atlas, published on CD-ROM on behalf of the Intergovernmental Oceanographic Commission and the International Hydrographic Organization as part of the General Bathymetric Chart of the Oceans, British Oceanographic Data Centre, Liverpool, UK, 2003.

Jickells, T. D., An, Z. S., Andersen, K. K., Baker, A. R., Bergametti, C., Brooks, N., Cao, J. J., Boyd, P. W., Duce, R. A., Hunter, K. A., Kawahata, H., Kubilay, N., LaRoche, J., Liss, P. S., Mahowald, N., Prospero, J. M., Ridgwell, A. J., Tegen, I., and Torres, R.: Global iron connections between desert dust, ocean biogeochemistry, and climate, Science, 308, 67-71, doi:10.1126/science.1105959, 2005.

Kerhervé, P., Heussner, S., Charrière, B., Stavrakakis, S., Ferrand, J. L., Monaco, A., and Delsaut, N.: Biogeochemistry and dynamics of settling particle fluxes at the Antikythira Strait (Eastern Mediterranean), Prog. Oceanogr., 44, 651-675, doi:10.1016/S0079-6611(99)00040-3, 1999.

Kontoyiannis, H., Theocharis, A., Balopoulos, E., Kioroglou, S., Papadopoulos, V., Collins, M., Velegrakis, A. F., and Iona, A.: Water fluxes through the Cretan Arc Straits, Eastern Mediterranean Sea: March 1994 to June 1995, Progr. Oceanogr., 44, 511529, doi:10.1016/s0079-6611(99)00044-0, 1999.

Kontoyiannis, H., Balopoulos, E., Gotsis-Skretas, O., Pavlidou, A., Assimakopoulou, G., and Papageorgiou, E.: The hydrology and biochemistry of the Cretan Straits (Antikithira and Kassos Straits) revisited in the period June 1997-May 1998, J. Marine Syst., 53, 37-57, doi:10.1016/j.jmarsys.2004.06.007, 2005.

Krom, M. D., Groom, S., and Zohary, T.: The Eastern Mediterranean, in: The Biogeochemistry of Marine Systems, edited by:
Black, K. D. and Shimmield, G. B., Blackwell Publishing, Oxford, 91-122, 2003.

Ladji, R., Yassaa, N., Balducci, C., and Cecinato, A.: Organic components of Algerian desert dusts, Chemosphere, 81, 925-931, doi:10.1016/j.chemosphere.2010.07.059, 2010.

Laflamme, R. E. and Hites, R. A.: The global distribution of polycyclic aromatic hydrocarbons in recent sediments, Geochim. Cosmochim. Ac., 42, 289-303, 1978.

Lee, B. H., Kostenidou, E., Hildebrandt, L., Riipinen, I., Engelhart, G. J., Mohr, C., DeCarlo, P. F., Mihalopoulos, N., Prevot, A. S. H., Baltensperger, U., and Pandis, S. N.: Measurement of the ambient organic aerosol volatility distribution: application during the Finokalia Aerosol Measurement Experiment (FAME2008), Atmos. Chem. Phys., 10, 12149-12160, doi:10.5194/acp10-12149-2010, 2010.

Lipiatou, E. and Saliot, A.: Fluxes and transport of anthropogenic and natural polycyclic aromatic hydrocarbons in the western Mediterranean Sea, Mar. Chem., 32, 51-71, 1991.

Lykousis, V., Smith, C., Salomidi, M., Stavrakakis, S., and Kontogiannis, H.: Hydro-sedimentary processes, deep corals and anthropogenic impacts in the canyons of the W. Cretan straits: new findings from HERMIONE ROV dives and fixed moorings, HERMIONE workshop, Malaga, 2011.

Mackenzie, A. S.: Applications of biological biomarkers in petroleum geochemistry, in: Advances in Petroleum Geochemistry, edited by: Brooks, J. and Welte, D., Academic Press, London, 115-214, 1984.

Malanotte-Rizzoli, P., Manca, B. B., D’Alcalà, M. R., Theocharis, A., Bergamasco, A., Bregant, D., Budillon, G., Civitarese, G., Georgopoulos, D., Mlchelato, A., Sansone, E., Scarazzato, P., and Souvermezoglou, E.: A synthesis of the Ionian Sea hydrography, circulation and water mass pathways during POEMphase I, Progr. Oceanogr., 39, 153-204, doi:10.1016/s00796611(97)00013-x, 1997.

Mandalakis, M., Besis, A., and Stephanou, E. G.: Particle-size distribution and gas/particle partitioning of atmospheric polybrominated diphenyl ethers in urban areas of Greece, Environ. Pollut., 157, 1227-1233, doi:10.1016/j.envpol.2008.12.010, 2009.

Marcomini, A., Pavoni, B., Donazzolo, R., and Orio, A. A.: Combined preparative and analytical use of normal-phase and reversed-phase high-performance liquid chromatography for the determination of aliphatic and polycyclic aromatic hydrocarbons in sediments of the Adriatic Sea, Mar. Chem., 18, 71-84, 1986.

Mayer, L. M.: Organic matter at the sediment-water interface, in: Organic Geochemistry, Principles and Applications, edited by Engel, M. N. and Macko, S. A., Plenum Press, New York, 171184, 1993.

Meador, T. B., Gogou, A., Spyres, G., Herndl, G. J., Krasakopoulou, E., Psarra, S., Yokokawa, T., De Corte, D., Zervakis, V., and Repeta, D. J.: Biogeochemical relationships between ultrafiltered dissolved organic matter and picoplankton activity in the Eastern Mediterranean Sea, Deep-Sea Res. Pt. II, 57, 1460-1477, doi:10.1016/j.dsr2.2010.02.015, 2010.

Mihalopoulos, N., Stephanou, E., Kanakidou, M., Pilitsidis, S., and Bousquet, P.: Tropospheric aerosol ionic composition in the Eastern Mediterranean region, Tellus B, 49, 314-326, 1997.

Millot, C. and Taupier-Letage, I.: Circulation in the Mediterranean Sea, Handbook Environ. Chem., 5K, 29-66, 2005. 
Neff, J.: Polycyclic Aromatic Hydrocarbons, Sources, Fates and Biological Effects, Applied Science Publ., London, 262 pp., 1979.

Nemr, A. E., Said, T. O., Khaled, A., El-Sikaily, A., and AbdAllah, A. M. A.: The distribution and sources of polycyclic aromatic hydrocarbons in surface sediments along the Egyptian Mediterranean coast, Environ. Monit. Assess., 124, 343-359, doi:10.1007/s10661-006-9231-8, 2007.

Nizzetto, L., Lohmann, R., Gioia, R., Jahnke, A., Temme, C., Dachs, J., Herckes, P., Di Guardo, A., and Jones, K. C.: PAHs in air and seawater along a North-South Atlantic transect: Trends, processes and possible sources, Environ. Sci. Technol., 42, 1580 1585, doi:10.1021/es07174142008, 2008.

Ohkouchi, N., Kawamura, K., and Wahata, H.: Distributions of three- to seven-ring polynuclear aromatic hydrocarbons on the deep sea floor in the Central Pacific, Environ. Sci. Technol., 33, 3086-3090, 1999.

Oros, D. R. and Ross, J. R. M.: Polycyclic aromatic hydrocarbons in San Francisco Estuary sediments, Mar. Chem., 86, 169-184, 2004.

OSPAR: Quality Status Report 2000: Region IV - Bay of Biscay and Iberian Coast, OSPAR Commission, London, 2000.

Parinos, C., Gogou, A., Bouloubassi, I., Stavrakakis, S., Plakidi, E., and Hatzianestis, I.: Sources and downward fluxes of polycyclic aromatic hydrocarbons in the open southwestern Black Sea, Org. Geochem., 57, 65-75, 2013.

Polymenakou, P. N., Mandalakis, M., Stephanou, E. G., and Tselepides, A.: Particle size distribution of airborne microorganisms and pathogens during an intense African dust event in the eastern Mediterranean, Environ. Health Persp., 116, 292-296, doi:10.1289/ehp.10684, 2008.

Poulos, S. E., Lykousis, V., Collins, M. B., Rohling, E. J., and Pattiaratchi, C. B.: Sedimentation processes in a tectonically active environment: The Kerkyra-Kefalonia submarine valley system (NE Ionian Sea), Mar. Geol., 160, 25-44, doi:10.1016/s00253227(99)00016-x, 1999.

Prahl, F. G. and Carpenter, R.: The role of zooplankton fecal pellets in the sedimentation of polycyclic aromatic hydrocarbons in Dabob Bay, Washington, Geochim. Cosmochim. Ac., 43, 19591972, 1979.

Prahl, F. G. and Carpenter, R.: Hydrocarbons in Washington coastal sediments, Estuar. Coast. Shelf S., 18, 703-720, 1984.

Prahl, F. G., De Lange, G. J., Scholten, S., and Cowie, G. L.: A case of post-depositional aerobic degradation of terrestrial organic matter in turbidite deposits from the Madeira Abyssal Plain, Org. Geochem., 27, 141-152, 1997.

Pusceddu, A., Bianchelli, S., Canals, M., Sanchez-Vidal, A., Durrieu De Madron, X., Heussner, S., Lykousis, V., de Stigter, H., Trincardi, F., and Danovaro, R.: Organic matter in sediments of canyons and open slopes of the Portuguese, Catalan, Southern Adriatic and Cretan Sea margins, Deep-Sea Res. Pt. I, 57, 441457, doi:10.1016/j.dsr.2009.11.008, 2010.

Ramdahl, T.: Retene - a molecular marker of wood combustion in ambient air, Nature, 306, 580-582, 1983.

Readman, J. W., Fillmann, G., Tolosa, I., Bartocci, J., Villeneuve, J.-P., Catinni, C., and Mee, L. D.: Petroleum and PAH contamination of the Black Sea, Mar. Pollut. Bull., 44, 48-62, 2002.

REMPEC: Study of maritime traffic flows in the Mediterranean Sea. A report prepared for the Regional Marine Pollution Emergency Response Centre for the Mediterranean Sea
(REMPEC) by Lloyd's Marine Intelligence Unit under the European Union financed MEDA regional project "Euromed co-operation on Maritime Safety and Prevention of Pollution from Ships - SAFEMED”, Final Report - Unrestricted Version, www.safemedproject.org/documents/safemed-1-documents/2. 3-maritime-traffic-flows-study/at_download/file, p. 17 and 32, July, (last access: August 29 2013), 2008.

Robinson, A. R., Malanotte-Rizzoli, P., Hecht, A., Michelato, A., Roether, W., Theocharis, A., Ünlüata, Ü., Pinardi, N., Artegiani, A., Bergamasco, A., Bishop, J., Brenner, S., Christianidis, S., Gacic, M., Georgopoulos, D., Golnaraghi, M., Hausmann, M., Junghaus, H. G., Lascaratos, A., Latif, M. A., Leslie, W. G., Lozano, C. J., Oguz, T., Özsoy, E., Papageorgiou, E., Paschini, E., Rozentroub, Z., Sansone, E., Scarazzato, P., Schlitzer, R., Spezie, G. C., Tziperman, E., Zodiatis, G., Athanassiadou, L., Gerges, M., and Osman, M.: General circulation of the Eastern Mediterranean, Earth-Sci. Rev., 32, 285-309, doi:10.1016/00128252(92)90002-b, 1992.

Roether, W., Manca, B. B., Klein, B., Bregant, D., Georgopoulos, D., Beitzel, V., Kovačević, V., and Luchetta, A.: Recent changes in eastern Mediterranean deep waters, Science, 271, 333-335, 1996.

Roussiez, V., Ludwig, W., Monaco, A., Probst, J. L., Bouloubassi, I., Buscail, R., and Saragoni, G.: Sources and sinks of sedimentbound contaminants in the Gulf of Lions (NW Mediterranean Sea): A multi-tracer approach, Cont. Shelf Res., 26, 1843-1857, doi:10.1016/j.csr.2006.04.010, 2006.

Saliot, A.: Natural Hydrocarbons in Sea Water, Chapt. 11, in: Elsevier Oceanography Series, Vol. 31, edited by: Duursma, E. K. and Dawson, R., Elsevier, 327-374, 1981.

Salvadó, J. A., Grimalt, J. O., López, J. F., Palanques, A., Heussner, S., Pasqual, C., Sanchez-Vidal, A., and Canals, M.: Role of dense shelf water cascading in the transfer of organochlorine compounds to open marine waters, Environ. Sci. Technol., 46, 2624-2632, doi:10.1021/es2038189, 2012.

Samanta, S. K., Singh, O. V., and Jain, R. K.: Polycyclic aromatic hydrocarbons: Environmental pollution and bioremediation, Trends Biotechnol., 20, 243-248, doi:10.1016/s01677799(02)01943-1, 2002.

Scarlett, A., Galloway, T. S., and Rowland, S. J.: Chronic toxicity of unresolved complex mixtures (UCM) of hydrocarbons in marine sediments, J. Soil. Sediment., 7, 200-206, doi:10.1065/jss2007.06.232, 2007.

Schlitzer, R.: Ocean Data View, http://odv.awi.de, 2011.

Schlitzer, R., Roether, W., Oster, H., Junghans, H. G., Hausmann, M., Johannsen, H., and Michelato, A.: Chlorofluoromethane and oxygen in the Eastern Mediterranean, Deep-Sea Res. A, 38, 1531-1551, 1991.

Simo, R., Grimalt, J. O., and Albaiges, J.: Loss of unburnedfuel hydrocarbons from combustion aerosols during atmospheric transport, Environ. Sci. Technol., 31, 2697-2700, doi:10.1021/es960994m, 1997.

Simoneit, B. R. T.: Some applications of computerized GC-MS to the determination of biogenic and anthropogenic organic matter in the environment, Int. J. Environ. An. Ch., 12, 177-193, 1982.

Simoneit, B. R. T.: Organic matter of the trophosphere - III. Characterization and sources of petroleum and pyrogenic residues in aerosols over the western United States, Atmos. Environ., 18, 5167, 1984. 
Sklivagou, E., Varnavas, S. P., Hatzianestis, I., and Kanias, G.: Assessment of aliphatic and polycyclic aromatic hydrocarbons and trace elements in coastal sediments of the Saronikos Gulf, Greece (Eastern Mediterranean), Mar. Georesour. Geotech., 26, 372393, doi:10.1080/10641190802474554, 2008.

Sporstøl, S., Gjøs, N., Lichtenthaler, R. G., Gustavsen, K. O., Urdal, K., Oreld, F., and Skei, J.: Source identification of aromatic hydrocarbons in sediments using GC/MS, Environ. Sci. Technol., 17, 282-286, 1983.

Theocharis, A., Nittis, K., Kontoyiannis, H., Papageorgiou, E., and Balopoulos, E.: Climatic changes in the Aegean Sea influence the Eastern Mediterranean thermohaline circulation (1986-1997), Geophys. Res. Lett., 26, 1617-1620, doi:10.1029/1999g1900320, 1999.

Tobiszewski, M. and Namieśnik, J.: PAH diagnostic ratios for the identification of pollution emission sources, Environ. Pollut., 162, 110-119, doi:10.1016/j.envpol.2011.10.025, 2012.

Tolosa, I., Bayona, J. M., and Albaiges, J.: Aliphatic and polycyclic aromatic hydrocarbons and sulfur/oxygen derivatives in Northwestern Mediterranean sediments: spatial and temporal variability, fluxes and budgets, Environ. Sci. Technol., 30, 2495-2503, 1996.

Tsapakis, M. and Stephanou, E. G.: Polycyclic aromatic hydrocarbons in the atmosphere of the Eastern Mediterranean, Environ. Sci. Technol., 39, 6584-6590, doi:10.1021/es0505321, 2005.

Tsapakis, M. and Stephanou, E. G.: Diurnal cycle of PAHs, nitroPAHs, and oxy-PAHs in a high oxidation capacity marine background atmosphere, Environ. Sci. Technol., 41, 8011-8017, doi:10.1021/es071160e, 2007.

Tsapakis, M., Stephanou, E. G., and Karakassis, I.: Evaluation of atmospheric transport as a nonpoint source of polycyclic aromatic hydrocarbons in marine sediments of the Eastern Mediterranean, Mar. Chem., 80, 283-298, doi:10.1016/s0304-4203(02)00132-9, 2003.

Tsapakis, M., Apostolaki, M., Eisenreich, S., and Stephanou, E. G.: Atmospheric deposition and marine sedimentation fluxes of polycyclic aromatic hydrocarbons in the eastern Mediterranean basin, Environ. Sci. Technol., 40, 4922-4927, 2006.
UNEP/MAP/MEDPOL: Sub-regional assessment of the Status of Marine and Coastal Ecosystems and of Pressures to the Marine and Coastal Environment Eastern Mediterranean Sea, UNEP(DEPI)/MED WG.350/Inf.4, Barcelona, Spain, 37-38, 2010.

Venkatesan, M. I.: Occurrence and possible sources of perylene in marine sediments-a review, Mar. Chem., 25, 1-27, 1988.

Venkatesan, M. I., Ruth, E., Steinberg, S., and Kaplan, I. R.: Organic geochemistry of sediments from the continental margin off southern New England, U.S.A. -Part II. Lipids, Mar. Chem., 21, 267-299, 1987.

Wakeham, S. G.: Aliphatic and polycyclic aromatic hydrocarbons in Black Sea sediments, Mar. Chem., 53, 187-205, doi:10.1016/0304-4203(96)00003-5, 1996.

Wakeham, S. G., Schaffner, C., and Giger, W.: Polycyclic aromatic hydrocarbons in Recent lake sediments. I. Compounds having anthropogenic origins, Geochim. Cosmochim. Ac., 44, 403-413, 1980.

Wang, Z., Fingas, M., and Page, D. S.: Oil spill identification, J. Chromatogr. A, 843, 369-411, doi:10.1016/s00219673(99)00120-x, 1999.

Witt, G.: Polycyclic Aromatic Hydrocarbons in Water and Sediment of the Baltic Sea, Mar. Pollut. Bull., 31, 237-248, 1995.

Yang, G. P.: Polycyclic aromatic hydrocarbons in the sediments of the South China Sea, Environ. Pollut., 108, 163-171, doi:10.1016/s0269-7491(99)00245-6, 2000.

Yilmaz, K., Yilmaz, A., Yemenicioglu, S., Sur, M., Salihoglu, I., Karabulut, Z., Karakoç, F. T., Hatipoglu, E., Gaines, A. F., Phillips, D., and Hewer, A.: Polynuclear aromatic hydrocarbons (PAHs) in the Eastern Mediterranean Sea, Mar. Pollut. Bull., 36, 922-925, doi:10.1016/s0025-326x(98)00094-0, 1998.

Yunker, M. B., Macdonald, R. W., Vingarzan, R., Mitchell, R. H., Goyette, D., and Sylvestre, S.: PAHs in the Fraser River basin: A critical appraisal of PAH ratios as indicators of PAH source and composition, Org. Geochem., 33, 489-515, doi:10.1016/s01466380(02)00002-5, 2002.

Yunker, M. B., Macdonald, R. W., Snowdon, L. R., and Fowler, B. R.: Alkane and PAH biomarkers as tracers of terrigenous organic carbon in Arctic Ocean sediments, Org. Geochem., 42, 11091146, 2011. 